\title{
Neuropeptide Receptor Transcript Expression Levels and Magnitude of Ionic Current Responses Show Cell Type- Specific Differences in a Small Motor Circuit
}

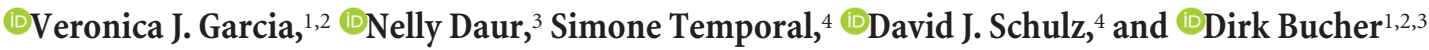 \\ ${ }^{1}$ Whitney Laboratory for Marine Bioscience, University of Florida, St. Augustine, Florida 32080, ${ }^{2}$ Department of Neuroscience, College of Medicine, \\ University of Florida, Gainesville, Florida 32610, ${ }^{3}$ Federated Department of Biological Sciences, New Jersey Institute of Technology and Rutgers University, \\ Newark, New Jersey 07102, and ${ }^{4}$ Department of Biological Sciences, University of Missouri, Columbia, Missouri 65211
}

We studied the relationship between neuropeptide receptor transcript expression and current responses in the stomatogastric ganglion (STG) of the crab, Cancer borealis. We identified a transcript with high sequence similarity to crustacean cardioactive peptide (CCAP) receptors in insects and mammalian neuropeptide $S$ receptors. This transcript was expressed throughout the nervous system, consistent with the role of CCAP in a range of different behaviors. In the STG, single-cell qPCR showed expression in only a subset of neurons. This subset had previously been shown to respond to CCAP with the activation of a modulator-activated inward current $\left(I_{\mathrm{MI}}\right)$, with one exception. In the one cell type that showed expression but no $I_{\mathrm{MI}}$ responses, we found CCAP modulation of synaptic currents. Expression levels within STG neuron types were fairly variable, but significantly different between some neuron types. We tested the magnitude and concentration dependence of $I_{\mathrm{MI}}$ responses to CCAP application in two identified neurons, the lateral pyloric (LP) and the inferior cardiac (IC) neurons. LP had several-fold higher expression and showed larger current responses. It also was more sensitive to low CCAP concentrations and showed saturation at lower concentrations, as sigmoid fits showed smaller $\mathrm{EC}_{50}$ values and steeper slopes. In addition, occlusion experiments with proctolin, a different neuropeptide converging onto $I_{\mathrm{MI}}$, showed that saturating concentrations of CCAP activated all available $I_{\mathrm{MI}}$ in LP, but only approximately two-thirds in IC, the neuron with lower receptor transcript expression. The implications of these findings for comodulation are discussed.

Key words: crustacean cardioactive peptide; neuromodulation; proctolin; stomatogastric

\section{Introduction}

Neuromodulation underlies flexibility of neural circuit operation, and all circuits are likely under control of multiple neuromodulators at all times (Harris-Warrick, 2011; Jordan and Sławińska, 2011; Marder, 2012; Nadim and Bucher, 2014). Therefore, understanding circuit dynamics requires not just knowledge of connectivity and baseline intrinsic and synaptic dynamics, but detailed quantitative information about neuromodulatory effects on all circuit components (Harris-Warrick, 2011; Bargmann, 2012; Bargmann and Marder, 2013; Nadim and Bucher, 2014). A neuromodulator can target multiple aspects of excitability and synaptic function in a single neuron, and differ-

Received Jan. 13, 2015; revised March 2, 2015; accepted March 22, 2015.

Author contributions: V.J.G., D.J.S., and D.B. designed research; V.J.G., N.D., and S.T. performed research; V.J.G., N.D., S.T., D.J.S., and D.B. analyzed data; V.J.G. and D.B. wrote the paper.

This work was supported by National Institute of Neurological Disorders and Stroke Grants NS058825 and NS083319 to D.B. We thank Drs. Jorge Golowasch and Farzan Nadim for helpful discussions; and Dr. Andrea Kohn for guidance with receptor cloning.

The authors declare no competing financial interests.

Correspondence should be addressed to Dr. Dirk Bucher, Department of Biological Sciences, New Jersey Institute of Technology, Central King Building, Room 337, 100 Summit Street, Newark, NJ 07102. E-mail: bucher@njit.edu.

S. Temporal's present address: Department of Neuroscience, University of Pennsylvania School of Medicine, Philadelphia, PA 19104.

DOI:10.1523/JNEUROSCI.0171-15.2015

Copyright $\odot 2015$ the authors $\quad 0270-6474 / 15 / 356786-15 \$ 15.00 / 0$ ent neuromodulators can share intracellular targets. In addition, a neuromodulator can have different targets across different neuron types. These multiple patterns of divergence and convergence, and the fine-tuning of cellular and synaptic properties they provide, present a major challenge to the understanding of circuit dynamics (Nadim and Bucher, 2014).

Mapping neuromodulator effects quantitatively across circuit components may still only be an attainable goal in numerically simpler invertebrate circuits consisting of individually identifiable neurons, such as those found in the crustacean stomatogastric ganglion (STG) (Nusbaum and Beenhakker, 2002; Marder and Bucher, 2007). In the STG, the patterns of divergence and convergence of neuromodulator effects are fairly distinct between neuropeptides and biogenic amines (Marder et al., 2005; Marder and Bucher, 2007; Stein, 2009; Nadim and Bucher, 2014). Monoamines, such as dopamine, act on all neurons to modulate a cell-type specific subset of multiple voltage-gated ion channels and also affect many synapses (Harris-Warrick et al., 1998; Harris-Warrick and Johnson, 2010; Harris-Warrick, 2011). In contrast, neuropeptides appear to have only a limited number of subcellular targets, and each neuropeptide acts on only a specific subset of circuit neurons. A number of neuropeptides converge onto the same voltage-gated modulator-activated inward current, $I_{\mathrm{MI}}$ (Golowasch and Marder, 1992; Swensen and Marder, 
2000; DeLong et al., 2009), and there are only a few reports of neuropeptide actions on synapses (Thirumalai et al., 2006; Zhao et al., 2011) or other voltage-gated ion channels (Rodriguez et al., 2013).

The finding that each peptide acts only on a specific subset of circuit neurons serves as a qualitative explanation for the specific effects of each peptide on circuit activity (Swensen and Marder, 2001). However, it is not clear to which degree quantitative differences play a role, for example, manifest in differences in receptor expression levels and concentration dependence of effects. There are two main reasons for the lack of quantitative understanding. First, despite the fact that the majority of neuromodulators acting on the STG are neuropeptides (Li et al., 2003; Marder and Bucher, 2007), G-protein-coupled receptors (GPCRs) have only been identified for biogenic amines (Clark et al., 2004, 2008). Second, $I_{\mathrm{MI}}$ responses to saturating concentrations of neuropeptide can be highly variable across individual animals (Goaillard et al., 2009).

Here we identify a putative neuropeptide receptor transcript with high sequence similarity to crustacean cardioactive peptide (CCAP) receptors in insects and show that expression is limited to the subset of STG neurons showing physiological responses. In two neuron types tested, differences in expression levels were consistent with differences in the magnitude and concentration dependence of modulatory effects.

\section{Materials and Methods}

Animals. All experiments were performed on wild-caught adult male Jonah crabs, Cancer borealis, purchased from Fresh Lobster. Crabs were kept in aquaria supplied with artificial sea water (Instant Ocean), cooled to a temperature of $9^{\circ} \mathrm{C}-13^{\circ} \mathrm{C}$. The animals were fed once a week until use. Before dissection, animals were anesthetized in ice for $30 \mathrm{~min}$. For each experiment, individual tissues were dissected under chilled physiological saline, composed of (in mM) as follows: $440 \mathrm{NaCl}, 11 \mathrm{KCl}, 13$ $\mathrm{CaCl}_{2}, 26 \mathrm{MgCl}_{2}$ (all from Fisher Scientific), and 10 HEPES (SigmaAldrich). The $\mathrm{pH}$ was adjusted to 7.45 .

RNA isolation and cDNA construction. Total RNA was isolated from tissues specific for each cDNA library application. To obtain the coding sequence of the $C$. borealis CCAP receptor ( $C b C C A P r)$, the brain, the two commissural ganglia (CoGs), the esophageal ganglion (OG), and the STG were pooled and used for RNA extraction. For analysis of $\mathrm{CbCCAPr}$ distribution, tissues were collected individually and included the brain, cardiac ganglion (CG), STG, OG, CoGs, thoracic ganglion (TG), the gastric mill muscle gm4, and the medial, dorsal muscle of the heart (HM). In both forms of RNA isolation, the TRI reagent protocol was used (Molecular Research Center). All tissues were placed directly into $360 \mu \mathrm{l}$ (STG, OG, CoGs, CG, gm4), $500 \mu \mathrm{l}$ (stomatogastric nervous system (STNS), brain, HM), or $750 \mu \mathrm{l}$ (TG, pooled STNS, and brain) TRI reagent homogenization buffer. The tissue was completely homogenized and then stored overnight at $-80^{\circ} \mathrm{C}$. The following day, tissues were thawed and $250 \mu \mathrm{l}$ TRI reagent was mixed into the homogenized TG or pooled STNS and brain samples. Samples were then processed according to the manufacturer's instructions and digested with DNase 1 (New England BioLab). Final RNA was suspended in 22, 30, or $50 \mu$ l DEPC-treated water, depending on tissue of origin. RNA concentration and quality were measured on a NanoDrop 2000c (Thermo Scientific).

Two forms of cDNA libraries were constructed. To clone $\mathrm{CbCCAPr}$, the SMART method (Clontech) was used to develop cDNA compatible with rapid amplification of cDNA ends (RACE). Primers are listed in Table 1. Briefly, total RNA was incubated with TempSwitch and $\mathrm{TRsa}\left(\mathrm{T}_{30}\right)$ oligos and then reverse transcribed using SuperScript III RT (Invitrogen). PCR amplification of the cDNA library was then performed using SMART oligos and LA Taq polymerase reagents (Takara Bio). To evaluate the distribution of $C b C C A P r$ throughout individual tissues of the animal, the standard SuperScript III RT protocol was used, using random hexamers and Oligo $\mathrm{d}(\mathrm{T})_{30}$ primers during reverse transcrip-
Table 1. Primers used for cloning, distribution, and quantification of the CbCCAPr ${ }^{a}$

\begin{tabular}{|c|c|}
\hline Primer & Sequence $\left(5^{\prime}\right.$ to $\left.3^{\prime}\right)$ \\
\hline \multicolumn{2}{|l|}{ cDNA library development } \\
\hline Template switch (TS) & AAGCAGTGGTATCAACGCAGAGTACGC $\mathrm{G}_{r} \mathrm{G}_{\mathrm{r}} \mathrm{G}$ \\
\hline $\operatorname{TRsa}(\mathrm{T})_{30}$ & CGCAGTCGGTACT $_{30}$ \\
\hline CapPCR & AAG CAG TGG TAT CAA CGC AGA GTA \\
\hline \multicolumn{2}{|l|}{ Cloning primers } \\
\hline Lu4Cap & $\begin{array}{l}\text { CGACGTGGACTATCCATGAACGCAAAGCAGTGGTAT- } \\
\text { CAACGCAGAGTA }\end{array}$ \\
\hline Lu4TRsa & CGACGTGGACTATCCATGAACGCACGCAGTCGGTACT $_{30}$ \\
\hline NsLu4 & $\begin{array}{l}\text { TCGAGCGGCCGCCCGGGCAGGTCGACGTGGACTATCCAT- } \\
\text { GAACGCA }\end{array}$ \\
\hline CbCCAPr.5.F & CCTACGTCTTGGTGGCTCTC \\
\hline CbCCAPr.8.R & TAATCTTGGCCTTTGGGATG \\
\hline CbCCAPr.4.R & AAGGGGAAGGTGATGACGGTCACT \\
\hline CbCCAPr.7.F & ATCGATTTCCCGAAGTTGTG \\
\hline \multicolumn{2}{|c|}{ Tissue distribution $P C R$ primers } \\
\hline CbCCAPr.5.F & CCTACGTCTTGGTGGCTCTC \\
\hline CbCCAPr.8.R & TAATCTTGGCCTTTGGGATG \\
\hline Cbßtub.1.F & TCTGTGCTGGATGTAGTCCG \\
\hline Cbßtub.3.R & AGAGTGGCGTTGTATGGCTC \\
\hline \multicolumn{2}{|l|}{ qRT-PCR primers } \\
\hline CbCCAPr.3.F & GGTGGCTCTGACTGTCTTCCTCTT \\
\hline CbCCAPr.4.R & AAGGGGAAGGTGATGACGGTCACT \\
\hline
\end{tabular}

${ }^{a}$ Primers used for development of $\mathrm{CDNA}$ libraries suitable for RACE, cloning of $\mathrm{CbCCAPr}$, tissue distribution, and qRT-PCR measurements. $\beta$ tub, Beta-tubulin; F, forward; R, reverse.

tion. The amount of RNA used for reverse transcription was limited by the total RNA isolated from the smallest nervous tissues, the OG and STG, resulting in only $\sim 125 \mathrm{ng}$ of RNA used from each tissue. Tissuespecific libraries were not amplified after reverse transcription, and any residual RNA was digested using RNase $\mathrm{H}$ (New England BioLabs). Both forms of cDNA were stored in aliquots at $-20^{\circ} \mathrm{C}$.

Cloning the receptor transcript. We first cloned and sequenced a partial cDNA fragment of $\mathrm{CbCCAPr}$ using an approach described previously (Schulz et al., 2006, 2007). Briefly, the receptor was amplified from a cDNA template derived from mixed nervous system tissue of C. borealis. We designed and used degenerate primer pairs based on conserved amino acid sequence compared across multiple invertebrate species. PCR products of predicted length were cloned into pGEM-T easy plasmid vector (Promega) and sequenced using traditional Sanger sequencing methods (University of Missouri DNA Core Facility). Sequences obtained were compared with orthologous sequences using BlastX (NCBI). With a putative fragment of CbCCAPr identified, gene-specific primers designed against the known fragment, and RACE oligo sequences (Table 1) were purchased from Integrated DNA Technologies. Touch-down and nested step-out PCRs to expand the amino- and carboxy termini of the fragment were performed using LA Taq polymerase reagents (Takara Bio), and products were cloned into pGEM-T vectors (Promega). Positive clones were sent to SeqWright for sequencing. Sequences comprising $\mathrm{CbCCAPr}$ were confirmed using BlastX (NCBI) and assembled using Lasergene SeqMan and SeqBuilder software (DNAstar). The assembled, putative coding sequence of $C b C C A P r$ contains an open reading frame of 1005 bases, identified and translated into amino acids using the ExPASy translate tool (Swiss Institute of Bioinformatics).

Sequence alignment and comparison. Multiple sequence alignment of $\mathrm{CbCCAPr}$ with other mammalian and arthropod Rhodopsin-like receptors was performed using MUSCLE (EMBL-EBI). Amino acid sequences were taken from the UniProtKB/Swiss-Prot database (EMBL-EBI). Accession numbers are listed in Table 2. ExPASy BoxShade server (SIB) was used to indicate conserved residues. The TMpred program (SIB) (Hofmann and Stoffel, 1993) was used to predict the transmembrane domains of CbCCAPr. Published transmembrane domains in the UniProtKB/ Swiss-Prot databank were used for human and arthropod receptors. Statistical significance was assumed at e-values $<0.001$.

To evaluate the phylogenetic relationship of $C b C C A P r$ with other Rhodopsin-like receptors, 61 protein sequences (accession numbers in Table 3) were aligned in MUSCLE, and phylogenetic analysis was con- 
Table 2. Accession numbers of select arthropod and human Rhodopsin-like receptors used in the multiple alignment shown in Figure $1^{a}$

\begin{tabular}{ll}
\hline Receptor & Accession number \\
\hline CbCCAPr & KM349850 \\
Apis mellifera CCAPr & XP_001122652.2 \\
Nasonia vitripennis CCAPr & XP_001602277.1 \\
T. castaneum CCAPr2 & NP_001076795.1 \\
T. castaneum CCAPr1 & NP_001076796.1 \\
Drosophila melanogaster CCAPr & NP_996297.3 \\
Culex quinquefasciatus CCAPr & XP_001847670.1 \\
Daphnia pulex CCAPr & EFX81678.1 \\
Homo sapiens NPSrA & NP_997055.1 \\
Homo sapiens NPSrB & NP_997056.1 \\
Homo sapiens V1Ar & NP_000697.1 \\
Homo sapiens V1Br & NP_000698.1 \\
Homo sapiens OXTr & NP_000907 \\
\hline
\end{tabular}

${ }^{a}$ Rhodopsin-like receptors: CCAPr; NPSrA, neuropeptide $S$ receptor $1 ; N P S r B$, neuropeptide $S$ receptor isoforms $B$; V1Ar, vasopressin receptor $1 \mathrm{~A}$; $\mathrm{V} 1 \mathrm{Br}$, vasopressin receptor $1 \mathrm{~B}$; $\mathrm{OXTr}$, oxytocin receptor.

ducted using MEGA software (version 6.0, ImageMagick Studio) (Tamura et al., 2013). A maximum likelihood consensus tree was inferred from 1000 bootstrap replicates, with the initial trees obtained by applying Neighbor-join and BioNJ algorithms to a matrix of pairwise distances estimated using a JTT model (Jones et al., 1992).

Tissue distribution of CbCCAPr transcript. To evaluate the quality of individual tissue cDNAs, primers were designed against $C$. borealis $\beta$-tubulin (CbßTub, GenBank accession number HM157288.1; Table 1) using PCR. Bands of 250 base pairs (bp) were amplified (see Fig. $3 B$ ) from 30 cycles of $30 \mathrm{~s}$ at $94^{\circ} \mathrm{C}, 30 \mathrm{~s}$ at $60^{\circ} \mathrm{C}$, and $1 \mathrm{~min}$ at $72^{\circ} \mathrm{C}$. Primers designed to amplify a $458 \mathrm{bp}$ fragment of $C b C C A P r$ (Table 1) were then used for screening the expression of each tissue (see Fig. $3 B$ ) using 40 cycles of $30 \mathrm{~s}$ at $94^{\circ} \mathrm{C}, 30 \mathrm{~s}$ at $57^{\circ} \mathrm{C}$, and $1 \mathrm{~min}$ at $72^{\circ} \mathrm{C}$. For both $\mathrm{Cb \beta Tub}$ and $\mathrm{CbCCAPr}$ PCR amplification, control libraries developed without reverse transcriptase (No-RT) were run in parallel (data not shown), to exclude genomic DNA contamination and account for high cycle number. Products were visualized on $1.5 \%-1.8 \%$ ethidium bromide-stained agarose gels. Bands of appropriate sizes were randomly excised and sequenced to confirm product identity.

CbCCAPr mRNA copy number quantification of individual STG neurons. Individual neurons were identified physiologically with intracellular recordings using established criteria and harvested for single-cell quantitative PCR as previously described (Schulz et al., 2006). Total RNA was isolated using the RNeasy extraction kit (QIAGEN), reverse transcribed with SuperScript III, and then used as template for real-time PCR with the fluorescent reporter SYBR Green (SA Biosciences). Primers (Table 1) were designed specifically for real-time PCR detection of CbCCAPr transcripts using Primer3 software.

Electrophysiological recordings. For electrophysiology experiments, the STNS was dissected from the stomach and transferred to a transparent Sylgard-lined (Dow Corning) dish in chilled physiological saline. A large petroleum jelly well was built around the STG for application of pharmacological agents. During all recordings, the preparation was continuously superfused with chilled saline $\left(11^{\circ} \mathrm{C}-13^{\circ} \mathrm{C}\right)$. Intracellular recordings of neuron somata were obtained after desheathing the STG, using sharp glass microelectrodes filled with $0.6 \mathrm{M} \mathrm{K}_{2} \mathrm{SO}_{4}$ and $20 \mathrm{mM} \mathrm{KCl}$ (resistance: $10-30 \Omega \mathrm{M}$ ). Intracellular recordings and voltage clamp were performed using Axoclamp 2B and 900A amplifiers (Molecular Devices). Electrode holders and headstages were mounted on mechanical (Leica) or motorized (Scientifica) micromanipulators. Traces were recorded using micro1401 mk2 digitizer boards (Cambridge Electronic Design) and Spike2 acquisition software (Cambridge Electronic Design, versions 7 and 8). Voltage and current traces were low-pass filtered in Spike2 to reduce noise as needed. Care was taken that filtering did not change the time course or amplitude of the signals of interest. Neurons were identified according to characteristic waveforms and by matching spike patterns to extracellular recordings from specific motor nerves. Extracellular recordings were obtained with stainless steel wire electrodes from petroleum jelly wells around motor nerves. Signals were amplified and filtered using A-M systems differential AC amplifiers (model 1700). All electrophysiological recordings were analyzed using custom programs written in the Spike2 script language.

Current measurements. Two electrode voltage-clamp recordings were used to determine the effect of different concentrations of CCAP (Bachem) on synaptic currents and the modulator-activated inward current $\left(I_{\mathrm{MI}}\right)$. Graded synaptic currents were recorded in response to depolarizing steps in a presynaptic neuron. Rhythmic activity and spiking were blocked by application of $100 \mathrm{~nm}$ TTX (Sigma-Aldrich). The postsynaptic neuron was held at $-50 \mathrm{mV}$, and the presynaptic neuron was stepped from a holding potential of $-60 \mathrm{mV}$. Short-term synaptic plasticity was tested with sets of five $0.5 \mathrm{~s}$ steps in the presynaptic neuron, at a frequency of $1 \mathrm{~Hz}$. To test for postsynaptic effects, outward currents in response to $0.5 \mathrm{~s}$ puffs of $10 \mathrm{~mm}$ glutamate (L-glutamic acid monosodium salt, Sigma) onto the STG neuropil were measured in the postsynaptic neuron at a holding potential of $-50 \mathrm{mV}$. Puffs were administered through a glass microelectrode with a broken tip, connected to a Toohey Spritzer (Toohey).

$I_{\mathrm{MI}}$ was measured in two different ways. In some experiments, IV curves were obtained from difference currents measured in response to voltage ramps (at $90 \mathrm{mV} / \mathrm{s}$ ) in control and CCAP (Golowasch and Marder, 1992; Goaillard et al., 2009). This was done in the presence of $100 \mathrm{~nm}$ TTX to block voltage-gated sodium channels, $1 \mu \mathrm{M}$ picrotoxin to block inhibitory glutamatergic synapses, $200 \mu \mathrm{M} \mathrm{CdCl}$ to block L-type calcium currents, and $20 \mathrm{~mm}$ tetraethylammonium to block delayed rectifier and calcium-dependent potassium currents. All blockers were purchased from Sigma-Aldrich. $I_{\mathrm{MI}}$ was obtained by subtracting the current response to the ramp in control saline from the response in CCAP, and current was subsequently plotted as a function of voltage. To test the concentration dependence of $I_{\mathrm{MI}}$, we held the membrane potential at $-20 \mathrm{mV}$ and applied CCAP in increasing concentrations from $100 \mathrm{pm}$ to $1 \mu \mathrm{M}$. Each concentration was washed in for $6 \mathrm{~min}$ and washed out for $8-15 \mathrm{~min}$. Blockers used in these experiments were the same as described for ramp protocols. Current amplitudes for each concentration were determined as the maximal difference to the holding current before CCAP application. In some experiments, the neuropeptide proctolin (Bachem) was applied in addition to CCAP to test for occlusion effects.

Statistical analysis. All statistical analyses and data plots were generated in SigmaPlot (versions 11 and 12, Systat Software). Unless otherwise indicated, all data are presented as means \pm SEM. Tests performed were $t$ tests (paired or unpaired, as appropriate) and one-way or two-way ANOVA, for repeated measures when appropriate. Pairwise comparisons of normally distributed data following ANOVA used the HolmSidak method. For not normally distributed data, Kruskal-Wallis ANOVA was performed on ranks, and pairwise comparisons were performed using Dunn's method for unequal group sizes, and Tukey tests for equal group sizes.

Postsynaptic current as a function of presynaptic voltage and $I_{\mathrm{MI}}$ as a function of the log of the CCAP concentration were fit with 3 parameter sigmoid functions of the following form: $y=a /\left(1+e^{-(x-x 0) / b}\right)$, where $a$ is the maximal current $\left(I_{\max }\right), \times 0$ the voltage of half-activation $\left(V_{1 / 2}\right.$, synaptic currents) or the half-maximal effective concentration $\left(\mathrm{EC}_{50}\right.$, $\left.I_{\mathrm{MI}}\right)$, and $b$ the slope factor. In this form, the slope factor is not the same as the often used Hill slope (Prinz, 2010), and it is smaller at steeper slopes. Final figure mounting and editing were done in Canvas (version 11, ACD Systems).

\section{Results}

The putative $C b C C A P r$ belongs to subfamily A6 within Rhodopsin-like GPCRs and is most closely related to other CCAP and neuropeptide $S$ receptors

CCAP is a cyclic nonapeptide with mirror-image sequence similarity to vasopressin (Stangier et al., 1987). It mainly acts as a neurohormone in arthropods and plays important roles in the regulation of heart contractions (Stangier et al., 1987; Tublitz, 1989; Cruz-Bermúdez and Marder, 2007; Fort et al., 2007; Wasielewski and Skonieczna, 2008; Estévez-Lao et al., 2013; Lee et al., 2013); molting behavior (Ewer and Truman, 1996; Phlip- 
Table 3. Accession numbers of the 61 protein sequences used in phylogenetic analysis $^{a}$

\begin{tabular}{|c|c|}
\hline Receptor & Accession No. \\
\hline \multicolumn{2}{|l|}{ CCAPr } \\
\hline Apis mellifera CCAPr & XP_001122652.2 \\
\hline Bombyx mori NPr A26 & BAG68425.1 \\
\hline CbCCAPr & KM349850 \\
\hline Daphnia pulex hypothetical (CAPr & EFX81678.1 \\
\hline Drosophila melanogaster CCAPr & CCAPR_DROME \\
\hline T. castaneum CCAPr1 & NP_001076796.1 \\
\hline T. castaneum CCAPr2 & NP_001076795.1 \\
\hline \multicolumn{2}{|l|}{ Neuropeptide S receptors } \\
\hline Anopheles gambiae NPSr-like GPCR3 & AAS77205.1 \\
\hline Bombyx mori NPr A30 & NP_001127746.1 \\
\hline Homo sapiens NPSrA & NP_997055.1 \\
\hline Homo sapiens NPSrB & NP_997056.1 \\
\hline Mus musculus NPSr & NP_783609.1 \\
\hline \multicolumn{2}{|l|}{ Vasopressin and oxytocin receptors } \\
\hline Danio rerio 0XTr & NP_001186299.1 \\
\hline Danio rerio OXTr-like & NP_001186298.1 \\
\hline Danio rerio Vasotocin $R \times 2$ & $X P \_683692.1$ \\
\hline Daphnia pulex AVP/OXTr & E9HG37_DAPPU \\
\hline Homo sapiens 0XTr & NP_000907.2 \\
\hline Homo sapiens V1Ar & NP_000697.1 \\
\hline Homo sapiens $\mathrm{V} 1 \mathrm{Br}$ & NP_000698.1 \\
\hline Homo sapiens V2r & NP_000045.1 \\
\hline Mus musculus 0XTr & NP_001074616.1 \\
\hline Mus musculus V1Ar & NP_058543.2 \\
\hline Mus musculus V1Br & NP_036054.1 \\
\hline Mus musculus V2r & NP_062277.1 \\
\hline T. castaneum AVP/OXTr & B1NWWV5_TRICA \\
\hline \multicolumn{2}{|l|}{ Adipokinetic hormone/GNRHr } \\
\hline Anopheles gambiae AKH/GNRHr & Q27J45_ANOGA \\
\hline Danio rerio GNRHr2 & NP_001138451.1 \\
\hline Danio rerio GNRHr4 & NP_001091663.1 \\
\hline Drosophila melanogaster GNRHrA & NP_477387.1 \\
\hline Drosophila melanogaster GNRHr2-A & NP_648571.1 \\
\hline Homo sapiens GNRHr isoform 1 & NP_000397.1 \\
\hline Mus musculus GNRHr & NP_034453.1 \\
\hline T. castaneum AKH/GNRHr & Q1W7L1_TRICA \\
\hline \multicolumn{2}{|l|}{ Gastrin/cholecystokinin receptors } \\
\hline Anopheles gambiae CCKr-like & XP_001237203.1 \\
\hline Danio rerio $\mathrm{CCKrA-like}$ & XP_697493.2 \\
\hline Danio rerio CCKr-likeX1 & $X P \_002663361.2$ \\
\hline Drosophila melanogaster CCKr-like & NP_001097021.1 \\
\hline Drosophila melanogaster CCKr-like17D3 & NP_001097023.1 \\
\hline Homo sapiens CCKrA & NP_000721.1 \\
\hline Homo sapiens Gastrin/CCKrB & NP_795344.1 \\
\hline Mus musculus CCKrA & NP_033957.1 \\
\hline Mus musculus CCKrB & NP_031653.1 \\
\hline \multicolumn{2}{|l|}{ Orexin receptors } \\
\hline Danio rerio ORXr2 & NP_001073337.1 \\
\hline Harpegnathos saltator $0 \mathrm{RX} 2$ & E2BMY8_HARSA \\
\hline Homo sapiens $\mathrm{ORX} \mathrm{r} 1$ & NP_001516.2 \\
\hline Mus musculus ORXr1 & NP_001156499.1 \\
\hline \multicolumn{2}{|l|}{ Pyroglutamylated RFamide peptide receptors } \\
\hline Danio rerio QRFPr & XP_001920042.3 \\
\hline Homo sapiens QRFPr & NP_937822.2 \\
\hline Mus musculus QRFPr & NP_937835.1 \\
\hline \multicolumn{2}{|l|}{ Neuropeptide FF receptors } \\
\hline Acromyrmex echinatior NPFFr2 & EGI57927.1 \\
\hline Danio rerio NPFFr1 & NP_001082858.1 \\
\hline Danio rerio NPFFr-like2 & NP_001165168.1 \\
\hline Danio rerio NPFFr2 & $X P \_690069.5$ \\
\hline Drosophila melanogaster NPFFr-like SIFr & NP_001163674.1 \\
\hline Homo sapiens NPFFr1 & NP_071429.1 \\
\hline Homo sapiens NPFFr2 isoform1 & $\begin{array}{l}\text { NP_004876.2 } \\
\text { (Table Continues) }\end{array}$ \\
\hline
\end{tabular}

Table 3. Continued

\begin{tabular}{|c|c|}
\hline Receptor & Accession No. \\
\hline Mus musculus NPFFr1 & NP_001170982.1 \\
\hline Mus musculus NPFFr2 & NP_573455.2 \\
\hline \multicolumn{2}{|l|}{ Frizzled receptors } \\
\hline Drosophila melanogaster FRZ & FRIZ_DROME \\
\hline Homo sapiens FRZ1 & NP_003496.1 \\
\hline Mus musculus FRZ1 & NP_067432.2 \\
\hline
\end{tabular}

pen et al., 2000; Park et al., 2003); gut movements, digestion, and metabolism (Veelaert et al., 1997; Donini et al., 2002; Sakai et al., 2004; Sakai et al., 2006); and oviduct contractions (Donini et al., 2001). In the STG, it acts on a number of neurons and alters rhythmic motor activity (Weimann et al., 1997; Richards and Marder, 2000; Swensen and Marder, 2000, 2001; DeLong et al., 2009), as well as contraction properties of target muscles (JorgeRivera et al., 1998). GPCRs specific for CCAP have been identified in a number of insect species (Cazzamali et al., 2003; Belmont et al., 2006; Arakane et al., 2008; Li et al., 2011; Lee et al., 2013), but so far not in crustaceans. We identified a fragment of a putative receptor cloned from C. borealis with $66 \%$ identity to the Tribolium castaneum crustacean cardioactive peptide receptor 2 (TbCCAPr2) (Park et al., 2008; Li et al., 2011) and used cDNA libraries constructed from RNA isolated from the STNS and brain to assemble the partial coding sequence. The putative CbCCAPr (GenBank accession number: KM349850) comprises 332 amino acids and a seven-transmembrane domain region typical of GPCRs. Comparison of CbCCAPr to known proteins using BlastX (NCBI) analysis showed sequence homology to members of the Rhodopsin-like family of GPCRs, including other arthropod CCAP receptors and human vasopressin and neuropeptide $S$ receptors.

Multiple alignment of CbCCAPr with arthropod CCAP receptors and human vasopressin, oxytocin, and neuropeptide $S$ (NPS) receptors revealed several regions of conserved residues (Fig. 1). Conserved residues occupy not only the transmembrane regions (TMs) but also intracellular and extracellular loops. Intracellular loop 3 showed the greatest diversity in residue compliment, aside from the carboxy- and amino-termini, which is likely due to specific residue motifs for coupling to G-proteins (Wess, 1997). Table 4 lists the percentage identity of amino acid residues between CbCCAPr and the full-length human and T. castaneum receptor sequences shown in the alignment in Figure 1. CbCCAPr is more similar to HsNPSrA than to HsV1Ar, with $41 \%$ sequence identity and $93 \%$ coverage compared with $33 \%$ and $89 \%$, respectively, but most similar to the TcCCAPr2 $(63 \%$ sequence identity and $96 \%$ coverage). Because the highest degree of similarity between GPCRs exists in the TM core structure (Bockaert and Pin, 1999), we also evaluated the relationships between receptor sequences excluding TMs. Without TMs, sequence identities dropped by 3\%-9\%, but e-values remained significant (Table 4).

To better support the identity of CbCCAPr, we performed phylogenetic analysis. CCAP, vasopressin, and NPS receptors belong to the subfamily A6 of Rhodopsin-like GPCRs (Joost and Methner, 2002), which additionally include gonadotropin releasing hormone receptors (GNRHr), cholecystokinin receptors $(\mathrm{CCKr})$, orexin receptors (ORXr), neuropeptide FF receptors (NPFFr), and pyroglutamylated receptors (QRFPr). Sequences representing each A6 receptor subclass were chosen from both 

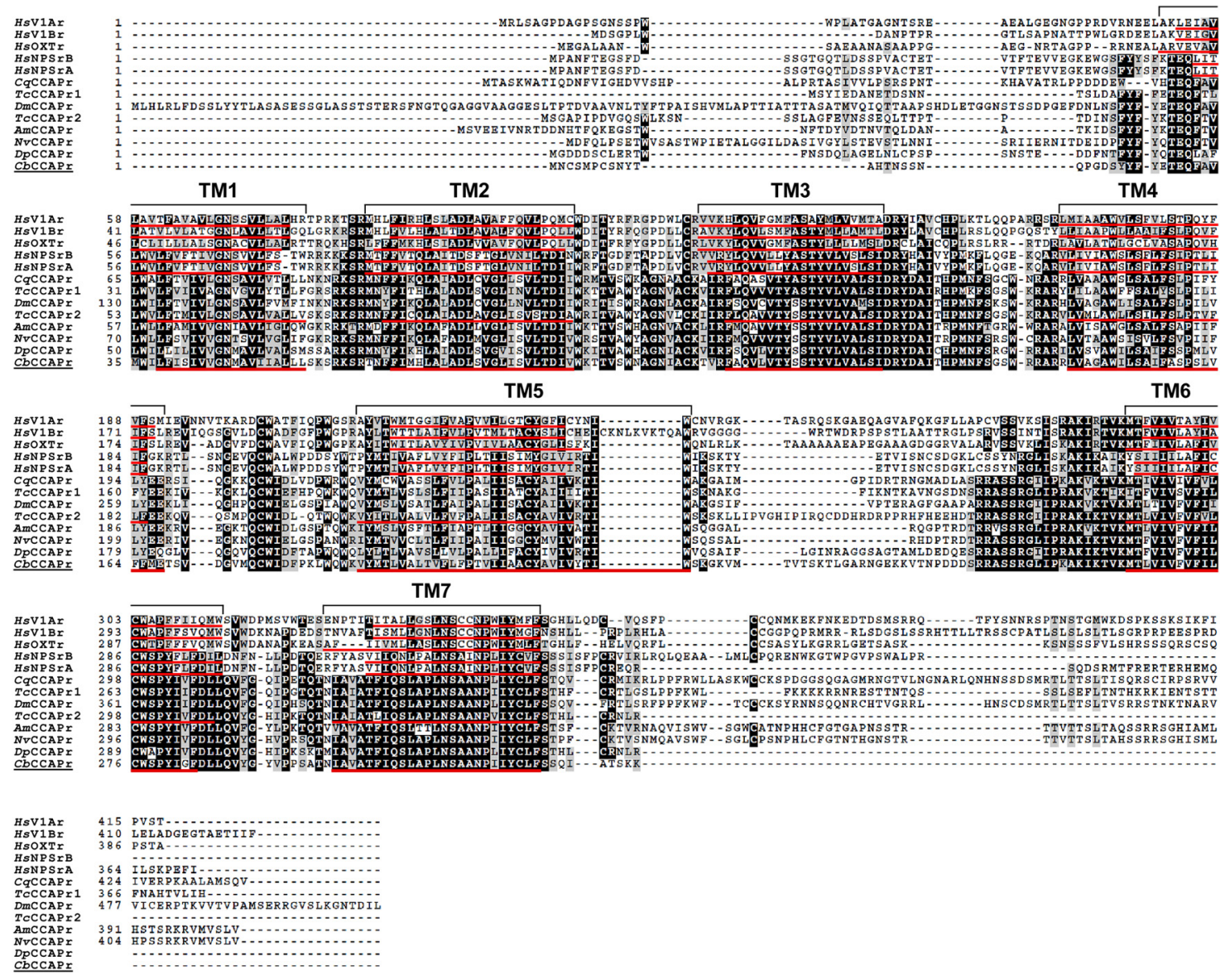

Figure 1. Multiple alignment of the CbCCAPr sequence with other arthropod CCAP receptor sequences and sequences for human vasopressin, oxytocin, and neuropeptide $S$ receptors. Black represents identical amino acid residues. Gray represents similar residues. Transmembrane regions of $\mathrm{CbCCAPr}$, human and $T$. castaneum receptors are underlined in red and labeled with brackets.

Table 4. Percent amino acid identity shared between CbCCAPr and select human and arthropod receptors, with and without transmembrane domain regions ${ }^{a}$

\begin{tabular}{|c|c|c|c|c|c|c|c|c|c|c|c|c|c|c|c|c|}
\hline & \multicolumn{4}{|c|}{$\mathrm{CbCCAPr}$} & \multicolumn{4}{|c|}{ HsV1Ar } & \multicolumn{4}{|c|}{ HsNPSrA } & \multicolumn{4}{|c|}{ TCCCAPr } \\
\hline & \multicolumn{2}{|c|}{ Whole } & \multicolumn{2}{|c|}{$(-) \mathrm{TM}$} & \multicolumn{2}{|c|}{ Whole } & \multicolumn{2}{|c|}{$(-) \mathrm{TM}$} & \multicolumn{2}{|c|}{ Whole } & \multicolumn{2}{|c|}{$(-) \mathrm{TM}$} & \multicolumn{2}{|c|}{ Whole } & \multicolumn{2}{|c|}{$(-) \mathrm{TM}$} \\
\hline & ID & e-value & ID & e-value & ID & e-value & ID & e-value & ID & e-value & ID & e-value & ID & e-value & ID & e-value \\
\hline HsV1Ar & 33 & 1e-52 & 30 & 3e-06 & & & & & 29 & $6 e-46$ & 27 & 7e-09 & 33 & $2 e-53$ & 34 & 7e-05 \\
\hline $\mathrm{HsV} 1 \mathrm{Br}$ & 33 & $3 e-57$ & 28 & $9 \mathrm{e}-09$ & 54 & $2 e-129$ & 47 & $3 e-53$ & 31 & 1e-46 & 27 & $2 \mathrm{e}-09$ & 34 & $6 e-51$ & 25 & $9 \mathrm{e}-06$ \\
\hline HsOXTr & 34 & $2 e-52$ & 28 & $1 \mathrm{e}-07$ & 54 & 2e-118 & 47 & $1 e-41$ & 34 & $2 e-46$ & 30 & $8 \mathrm{e}-11$ & 34 & 2e-49 & 38 & $3 e-05$ \\
\hline HsNPSrA & 41 & 4e-81 & 36 & $3 e-17$ & 29 & 6e-46 & 27 & 7e-09 & & & & & 41 & $9 e-86$ & 33 & 6e-19 \\
\hline HsNPSrB & 41 & $2 \mathrm{e}-80$ & 36 & 3e-17 & 29 & $2 \mathrm{e}-45$ & 26 & 1e-08 & 99 & 0.0 & 99 & 7e-150 & 41 & $3 e-85$ & 33 & 1e-18 \\
\hline TCCCAPr2 & 63 & 1e-151 & 54 & $7 e-55$ & 33 & $2 e-53$ & 34 & 7e-05 & 41 & $9 e-86$ & 33 & $6 e-19$ & & & & \\
\hline
\end{tabular}

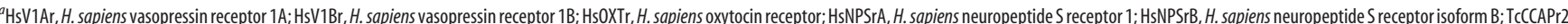
T. castaneum crustacean cardioactive peptide receptor 2; Whole, entire protein sequence; (-) TM, transmembrane domain regions removed; ID, sequence identity (in percent).

vertebrate and invertebrate species. Frizzled GPCRs from vertebrates and Drosophila were used as the out-group. The maximum-likelihood consensus tree in Figure 2 shows CbCCAPr clusters with NPS and CCAP receptors and is most closely related to a hypothetical CCAPr predicted from the genome of the only other crustacean in the study, Daphnia pulex. The most closely related receptor group to CCAP and NPS receptors consists of vasopressin and oxytocin receptors. The group of CCAP, NPS, vasopressin, and oxytocin receptors is most closely related to GNRH receptors, consistent with a previous study (Pitti and Manoj, 2012). All other receptors cluster according to the receptor groups within subfamily A6, whereas Frizzled receptors are separate. The location of the CbCCAPr in the consensus tree strongly suggests that the putative sequence encodes for a GPCR with high similarity to arthropod CCAP receptors.
$\mathrm{CbCCAPr}$ is expressed in nervous tissues and the gastric mill gm4 muscle

Because of the widespread and diverse effects of CCAP on the nervous system and elsewhere, we investigated receptor mRNA expression throughout a range of different tissues. Five animals were used to extract RNA from six nervous tissues and two muscles (Fig. $3 A$ ): the thoracic ganglion, brain, cardiac ganglion, STG, CoGs, esophageal ganglion, heart muscle, and the gastric mill muscle gm4.

Figure $3 B$ shows expression of $C b C C A P r$ by each of the six nervous tissues, but at varying levels across individual animals. $C b \beta T u b$ is shown as a positive control. Libraries used as negative controls were generated in parallel and without reverse transcriptase (data not shown). The CoG sample in Animal 1 was the only one not showing expression. Figure $3 C$ 


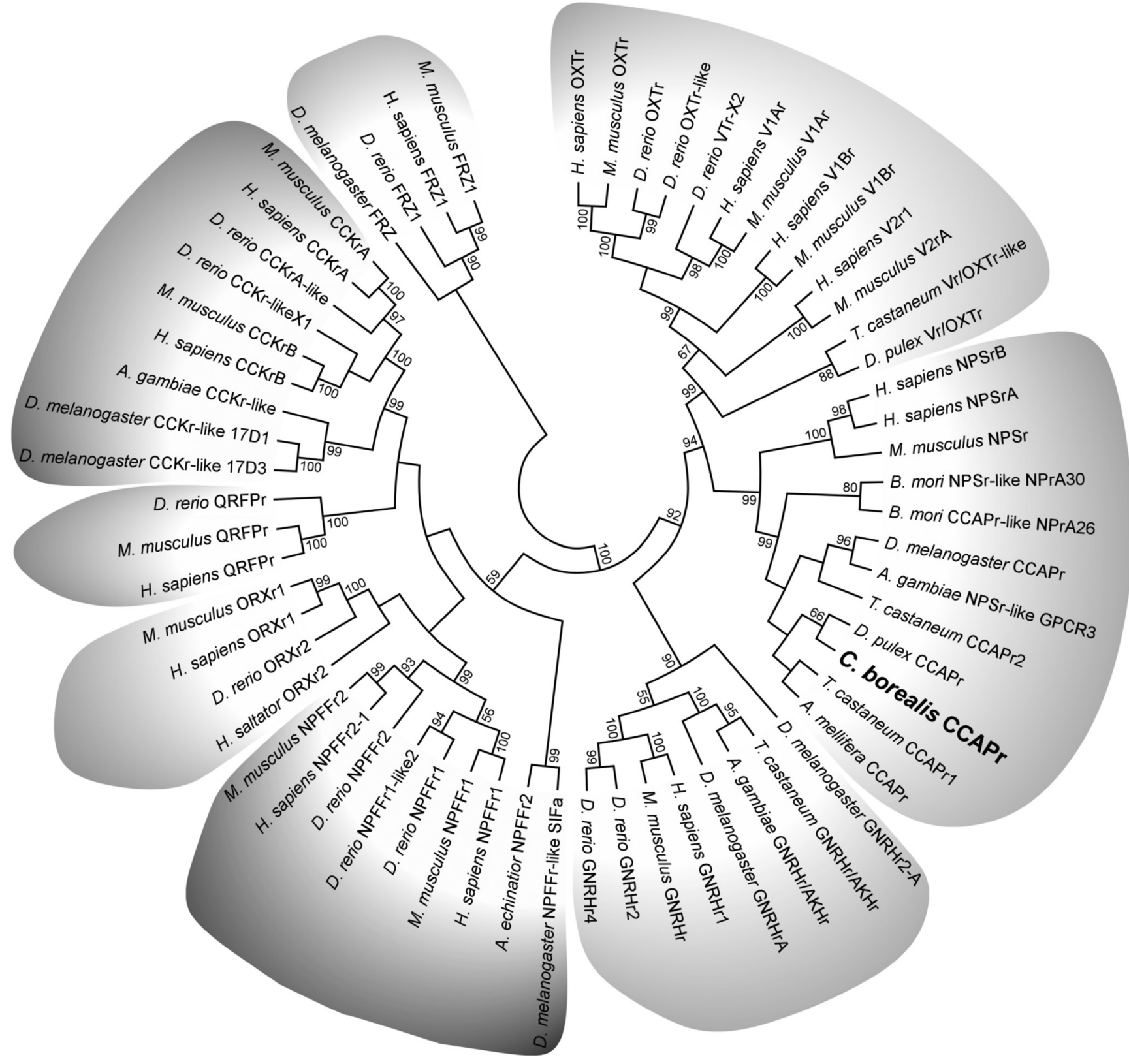

Figure 2. Maximum-likelihood consensus tree of CbCCAPr and representatives of receptor types found in the A6 subfamily of Rhodopsin-like GPCRs. Sequences used for analysis include vasopressin receptors (V1Ar, V1Br, V2r), oxytocin receptors (OXTr), neuropeptide S receptors (NPSrA, NPSrB), gonadotropin releasing hormone receptors (GNRHr), neuropeptide FF receptors (NPFFr), orexin receptors (ORXr), pyroglutamylated RFamide peptide receptors (QRFPr), and cholecystokinin receptors (CCKr). Frizzled receptors (FRZ) were used as the out-group. Percentage bootstrap values of 1000 replicates are shown at the nodes; values $<50 \%$ are hidden. Clades are shaded according to receptor type.

shows very weak or absent expression in the heart muscle but robust expression in $g m 4$.

\section{CbCCAPr mRNA is expressed at varying levels across neuron types in the STG}

Figure $3 B$ shows that $C b C C A P r$ mRNA is expressed in the STG. We also determined the expression levels across different neuron types in the STG using single-cell qRT-PCR. In C. borealis, the STG contains 25 or 26 neurons, some of types that exist as a single copy and some of types that have multiple copies (Kilman and Marder, 1996). The majority of these neurons are members of two interacting central pattern-generating circuits controlling pyloric and gastric mill muscles of the stomach (Marder and Bucher, 2007). To varying degrees, most STG neurons take part in both the faster pyloric rhythm and the slower gastric mill rhythm (Weimann et al., 1991; Bucher et al., 2006), but for simplicity we separated the 13 neuron types into pyloric and gastric mill neurons, mostly based on the muscles that they control (Weimann et al., 1991). Figure 4 shows single measurements and means of mRNA copy numbers by cell type. There was substantial variability in expression levels within cell types (see coefficients of variation), and some cell types showed no expression at all. Among those that did show expression, mean levels were cell typedependent and ranged from a few hundred copies to $>2000$. Pairwise comparisons revealed differences between the anterior median (AM) neuron and the dorsal gastric (DG) neurons, AM and the inferior cardiac (IC) neuron, the lateral gastric (LG) neuron and DG, LG and IC, the lateral pyloric (LP) and DG, and LP 


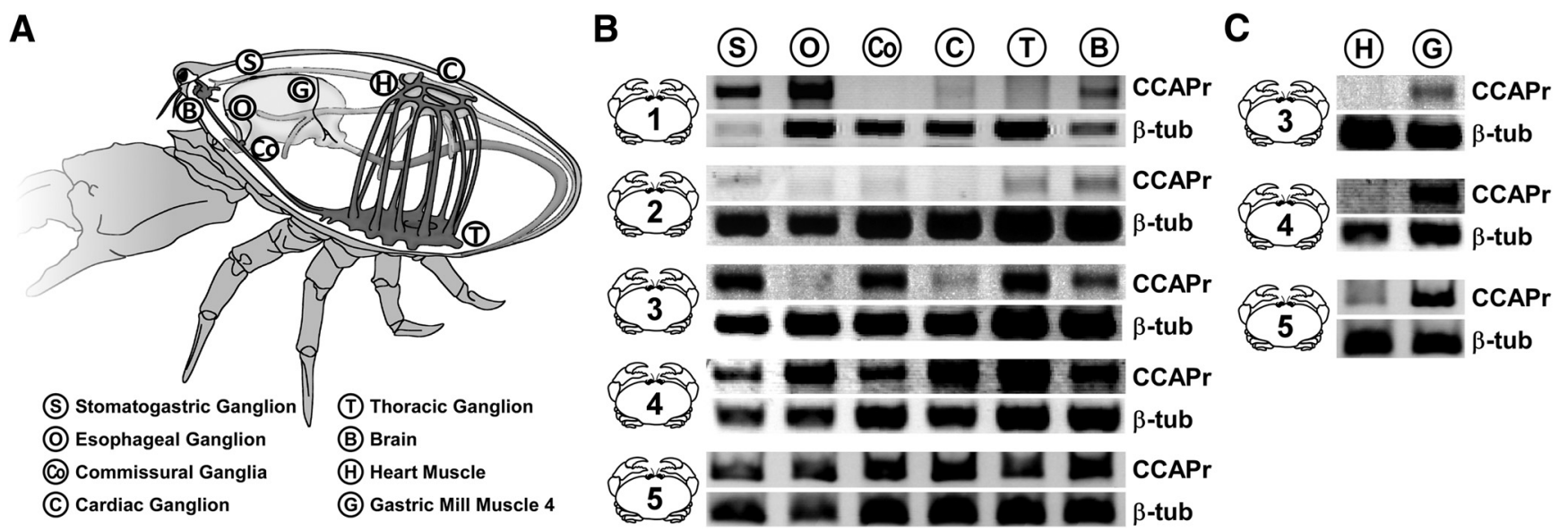

Figure 3. $C b C C A P r$ RNA is present throughout the nervous system and in a gastric mill muscle. $A$, Schematic of $C$. borealis anatomy, indicating the tissues harvested. $B, C$, Negative images of ethidium bromide-stained agarose gels from PCR amplification of $C b C C A P r$ (top bands, $485 \mathrm{bp}$ ) and $C b \beta$-tubulin (bottom bands, $250 \mathrm{bp}$ ) from 5 animals.

and IC. In some cell types with a low mean expression level, some individual samples showed no expression at all. This was true for IC in 1 of 16 samples, for the medial gastric (MG) neuron in 2 of 6 samples, and for DG in 6 of 8 samples.

The effect of CCAP on intrinsic excitability has been tested for all STG neurons, in two different ways. Among pyloric neurons, voltage-clamp experiments revealed that CCAP activates $I_{\mathrm{MI}}$ in $\mathrm{LP}$ and IC, but not in pyloric dilator (PD), PY, VD, and LPG (Swensen and Marder, 2001). $I_{\mathrm{MI}}$ cannot be measured in voltage clamp from the anterior burster $(\mathrm{AB})$ neuron, likely due to insufficient space clamp in soma recordings, but CCAP depolarizes synaptically isolated $\mathrm{AB}$ neurons in current-clamp recordings (Swensen and Marder, 2001). Among gastric neurons, only LG has been shown to activate $I_{\mathrm{MI}}$ in response to CCAP application (DeLong et al., 2009). However, all other gastric mill neurons have been tested for depolarizing responses in current clamp (Kirby and Nusbaum, 2007). CCAP depolarized interneuron 1 (Int1) and AM, but not MG, DG, and the GM neurons. Cell types responsive to CCAP are shown in bold in Figure 4. Among pyloric neurons, CbCCAPr mRNA expression matches effects on intrinsic excitability, with the exception of the ventricular dilator (VD) neuron, which expresses at relatively low levels but in which $I_{\mathrm{MI}}$ is not activated in response to CCAP. Among gastric mill neurons, CbCCAPr mRNA expression matches effects on intrinsic excitability unambiguously for AM, LG, and Int1, which show relatively high expression levels and also show physiological responses to CCAP, and GM, which neither shows expression nor responses. DG does not show depolarizing responses to CCAP. We found CbCCAPr mRNA each pair). ${ }^{*} p<0.05$.

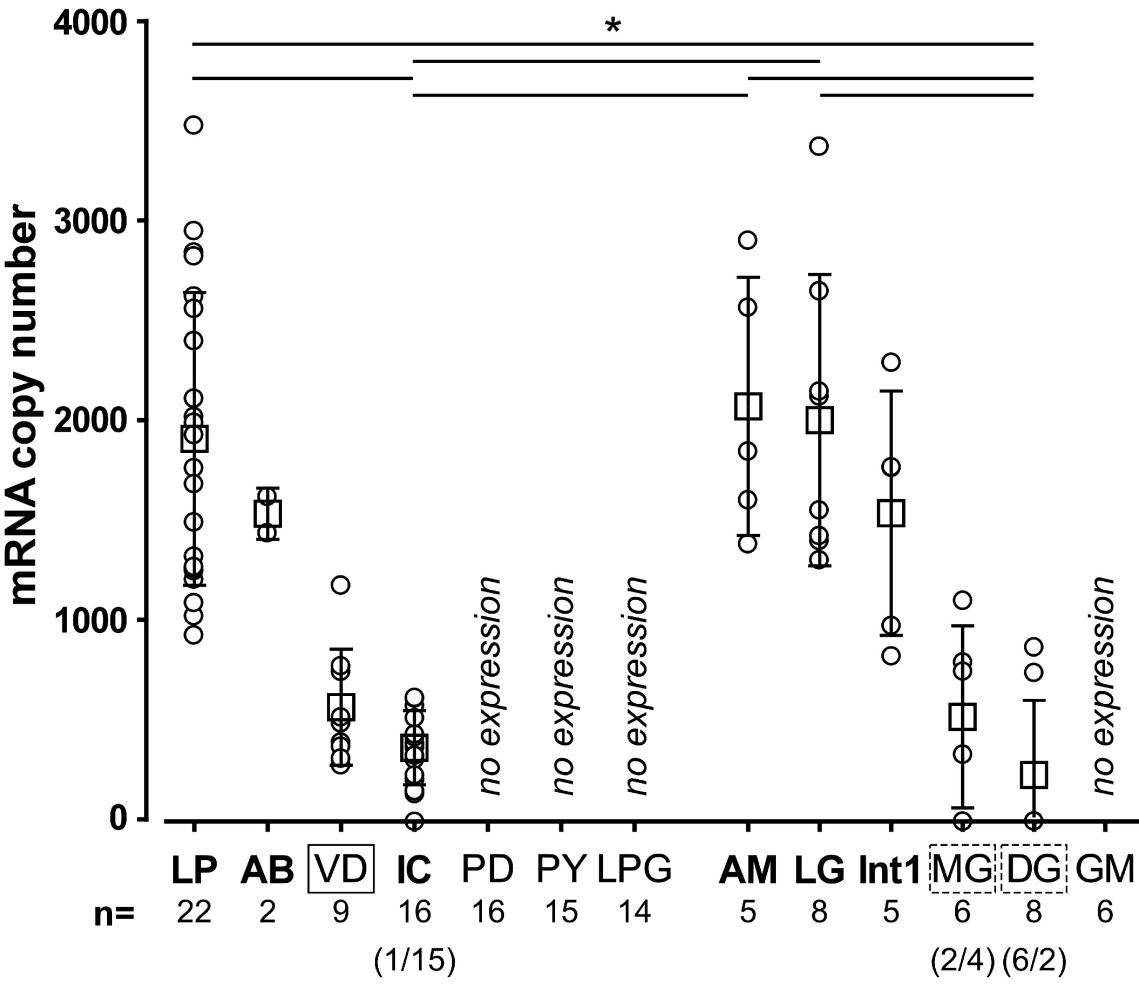

C.V.= $0.390 .090 .530 .54 \quad-\quad-\quad-\quad 0.320 .370 .400 .921 .86 \quad-$

"pyloric neurons"__ _ _ _gastric mill neurons"-

Figure 4. Single-cell qRT-PCR shows that $C b C C A P r$ is expressed in a subset of $S T G$ neurons and at varying levels between cell types. For each cell type, mRNA copy numbers are plotted both for individual measurements (circles) and for means (squares). Cell types included all pyloric and gastric mill neurons ( $L P ; A B ; V D ; I C ; P Y$, pyloric constrictor neuron; $L P G$, lateral posterior gastric neuron; $A M$; Int1, interneuron 1; DG; GM). Cell types previously found to display physiological responses to CCAP are shown in bold. Solid line box around VD represents a mismatch between expression and physiological responsiveness. Dashed boxes around MG and DG represent ambiguity in expression and responsiveness. The number of individual cells measured for each cell type is given in the line beneath the cell type names. For IC, MG, and DG, the numbers in parentheses indicate the number of cells showing no expression/number of cells showing expression. The coefficients of variance are given to indicate variability of expression levels. Mean expression levels were cell type-dependent (one-way ANOVA on ranks, $p<0.001$ ). Pairwise comparisons (Dunn's method) revealed differences as indicated by solid lines on top of the plot ( $p<0.05$ for

expression in DG, but in only 2 of 8 samples. MG shows a somewhat ambiguous response to CCAP (Kirby and Nusbaum, 2007). A weak excitation is seen in low $\mathrm{Ca}^{2+}$ saline but ceases when responses in neurons that are electrically coupled to MG are sup- 
A

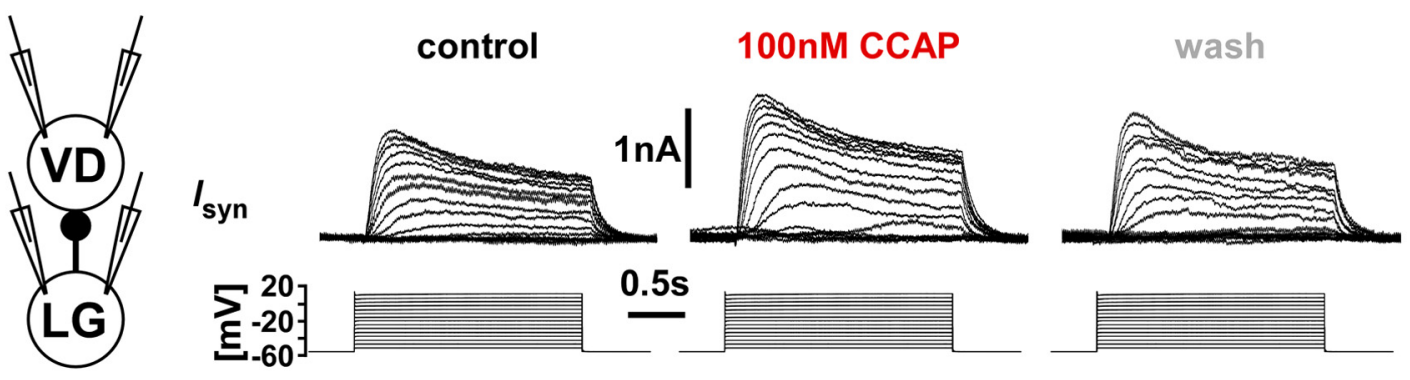

B

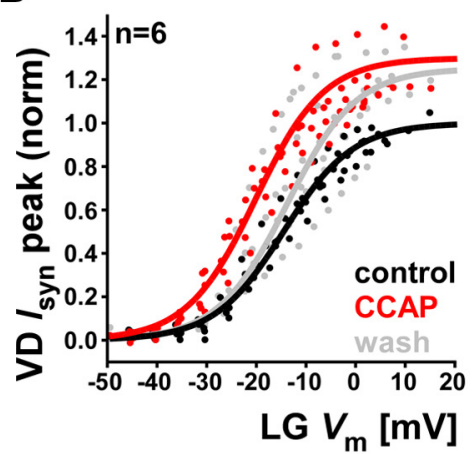

C

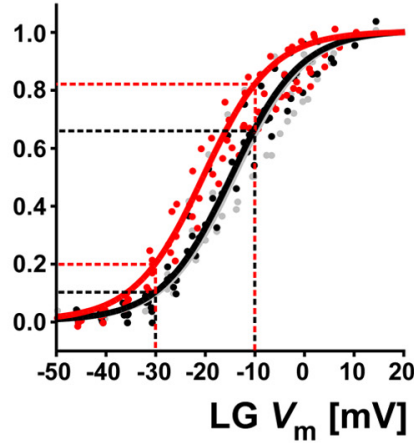

D

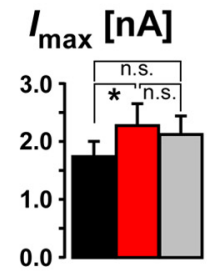

$v_{1 / 2}[\mathrm{mV}]$

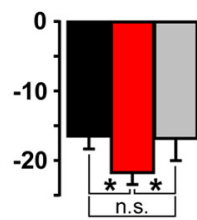

slope factor

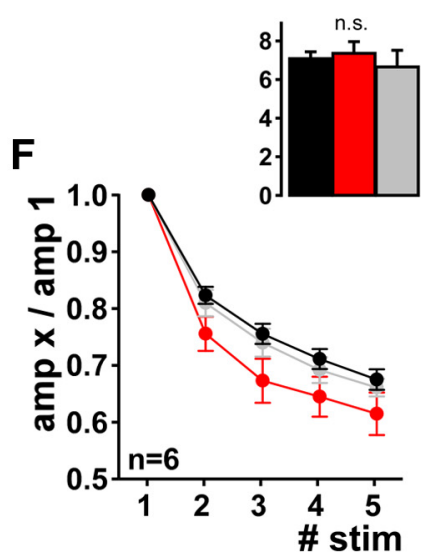

Figure 5. CCAP modulates strength and dynamics of the $L G$ to VD graded chemical synapse. $A$, Dual two-electrode voltage-clamp measurements of synaptic currents in VD (holding potential: $-50 \mathrm{mV}$ ) in response to voltage steps in LG. Traces were averaged from 3 to 5 repeats of the same stimulation protocol. $\boldsymbol{B}$, Cross-synaptic IV data for all three treatments from six experiments, normalized to $I_{\max }$ obtained from sigmoid fits to the control values in each experiment. Overlaid sigmoid curves were obtained by averaging sigmoidal fit parameters across experiments. $C$, The same cross-synaptic IV data as shown in $\boldsymbol{B}$, but normalized to $I_{\max }$ obtained from sigmoid fits to values from each separate treatment. Dashed lines indicate the increase of synaptic currents at two different voltages that is solely due to the shift in $V_{1 / 2}$. D, Statistical comparison of the sigmoidal fit parameters. One-way repeated-measures ANOVA showed significant differences across treatments for $I_{\text {max }}$ $(p<0.05)$ and $V_{1 / 2}(p<0.05)$, but not the slope factor $(p=0.69)$. Asterisks indicate results from Holm-Sidak paired comparisons. $E$, VD neuron current responses to five $0.5 s$ steps at $1 \mathrm{~Hz}$ and at two different depolarization levels in the $L G$ neuron. The synaptic current shows depression at both levels. Traces were averaged from 4 or 5 repeats of the same stimulation protocol. $F$, Plot of the mean response amplitudes, normalized to the first of the five responses. Two-way repeated-measures ANOVA showed a significant difference between treatments $(p<0.01)$, but no interaction between treatment and stimulus number $(p=0.37)$, meaning that the increase in depression was fairly uniform for stimuli 2 to 5 . Holm-Sidak paired comparisons showed a significant difference between control and CCAP $(p<0.01)$ and CCAP and wash $(p<0.01)$, but not control and wash $(p=0.77)$. n.s., Not significant.

pressed. We found CbCCAPr mRNA expression in MG, but in only 4 of 6 samples. We conclude that there is some ambiguity in the cases of MG and DG, but that the only definitive mismatch between $C b C C A P r$ mRNA expression and previously published physiological responses to CCAP exists for the VD neuron.

\section{CCAP acts on the LG to VD synapse}

CCAP does not activate $I_{\mathrm{MI}}$ in the VD neuron, but expression of $\mathrm{CbCCAPr}$ mRNA suggests that CCAP may act on other subcellular targets. We therefore wanted to test whether CCAP acts on synaptic connections involving VD. Neuropeptide effects on synapses in the STG have not been studied extensively, but 2 cases involving other neuropeptides have been described (Thirumalai et al., 2006; Zhao et al., 2011). VD has no known chemical output synapses within the STG but receives graded inhibitory inputs from $\mathrm{AB}$ and $\mathrm{LG}$ through glutamatergic synapses (Nusbaum and Beenhakker, 2002). We used dual two-electrode voltage clamp to measure the LG to VD connection in control, $100 \mathrm{~nm} \mathrm{CCAP,} \mathrm{and}$ after a minimum of 15 min wash (Fig. 5A). Depolarizing voltage steps in LG elicited graded outward current responses in VD, with a transient and a sustained component typical for chemical synapses in the STG (Graubard et al., 1980; Manor et al., 1997; Zhao et al., 2011). The example traces in Figure $5 A$ show an increase in $I_{\text {syn }}$ in the presence of CCAP. We quantified the dependence of the peak synaptic current $\left(I_{\text {syn }}\right.$ peak) on presynaptic voltage. On average, CCAP increased $I_{\text {syn }}$ peak by $\sim 30 \%$ (Fig. $5 B$ ) and shifted the dependence on presynaptic voltage (voltage of half activation, $V_{1 / 2}$ ) by $\sim-5 \mathrm{mV}$ (Fig. $5 C$ ). Figure $5 D$ shows that the change in $I_{\text {syn }}$ peak was significant but did not wash. However, the shift in $V_{1 / 2}$ was also significant, and did wash. The slope factor did not 
A

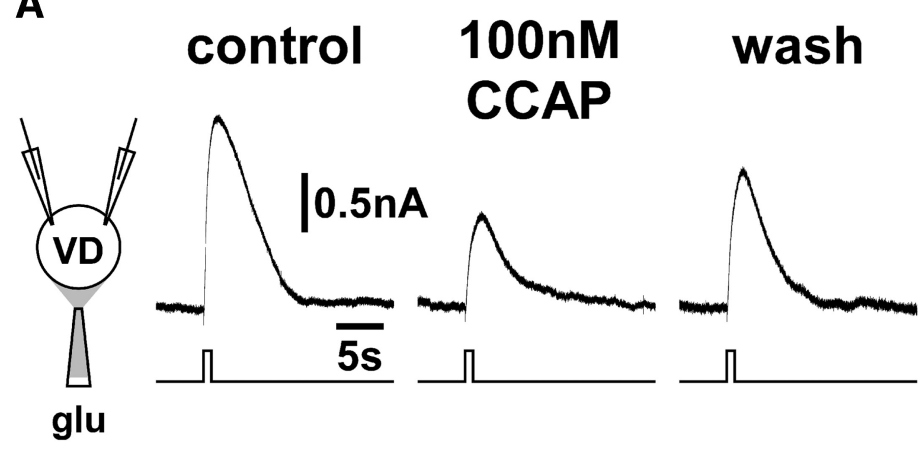

B

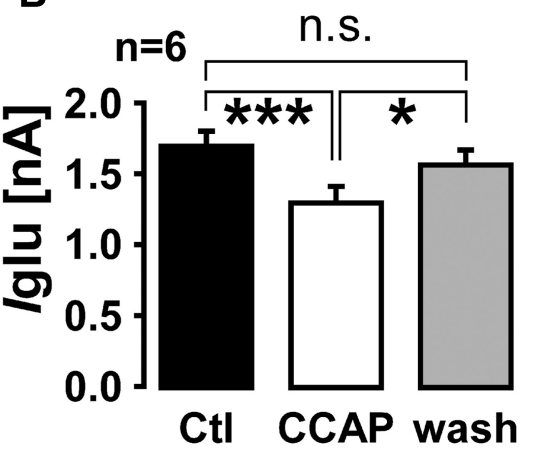

Figure 6. CCAP reduces the current response to glutamate application in the VD neuron. $\boldsymbol{A}, \mathrm{VD}$ current responses to $500 \mathrm{~ms}$ puff of $10 \mathrm{~mm}$ glutamate onto the STG neuropil in control saline (including $100 \mathrm{~nm}$ TTX), $100 \mathrm{~nm}$ (CAP, and after wash. Traces are averages from 4 to 8 repeats. $\boldsymbol{B}$, Mean \pm SEM responses from six experiments. Responses were significantly different between control saline (including $100 \mathrm{~nm}$ TTX) and (CAP, and (CAP and wash, but not between control and wash (one-way ANOVA for repeated measures, $p<0.01 ;$ Holm-Sidak paired comparisons). ${ }^{*} p<0.05$. ${ }^{* * *} p<0.001$. n.S., Not significant.

change. Even when only the change in $\mathrm{V}_{1 / 2}$ is considered (Fig. $5 C)$, CCAP increased the synaptic current substantially at a given presynaptic voltage $(25 \%-95 \%$ increase between -10 and -30 $\mathrm{mV}$, dashed lines).

The effective strength of a synapse during repetitive activation depends critically on short-term synaptic dynamics (Nadim and Manor, 2000), and the graded synapses in the STG usually show substantial depression (Manor et al., 1997; Mamiya et al., 2003). We therefore also tested the effect of CCAP on synaptic dynamics. Figure $5 E$ shows the VD current responses to repetitive stimulation at two different levels of LG depolarization in control, CCAP, and wash. We tested voltage steps of different amplitude because at STG synapses the sign of synaptic dynamics can depend on presynaptic voltage level (Zhao et al., 2011). For the range of $L G$ voltages from -30 to $0 \mathrm{mV}$, the $\mathrm{LG}$ to $\mathrm{VD}$ synapse was always depressing ( $n=5$, with $2-5$ voltage values per experiment; data not shown). We therefore only report responses to LG depolarization to $-10 \mathrm{mV}$. Figure $5 F$ shows that CCAP increased the amount of synaptic depression moderately $(<10 \%)$ over the whole course of repeated stimulation.

These results show that CCAP alters the LG to VD synaptic connection. We did not measure the $\mathrm{AB}$ to $\mathrm{VD}$ connection, the other synapse onto VD, but both LG (Kirby and Nusbaum, 2007; DeLong et al., 2009) and AB (Swensen and Marder, 2001) respond to CCAP in synaptic isolation, and both express $\mathrm{CbCCAPr}$ mRNA (Fig. 4). Consequently, the effects on synaptic strength and dynamics between LG and VD, and potentially AB and VD, could be either due to presynaptic or postsynaptic CCAP targets, or both. To test for unambiguously postsynaptic effects (i.e., to determine whether CCAP receptors on VD play a role in synaptic modulation), we also measured the currents in VD in response to glutamate, the transmitter used by both LG and AB. Figure $6 \mathrm{~A}$ shows the multiple seconds long outward current responses to puffs of glutamate onto the STG neuropil in control, CCAP, and after washing for a minimum of $10 \mathrm{~min}$. Surprisingly, CCAP reduced the amplitude of the response, on average by $24 \%$ (Fig. $6 B)$. Therefore, postsynaptic effects of CCAP oppose the overall strengthening of the LG to VD synapse. We continuously monitored the input resistance $\left(R_{\mathrm{in}}\right)$ of VD in between glutamate puffs. $R_{\text {in }}$ was similar in all conditions and not affected by CCAP (median value control: 11.0 M $\Omega$, CCAP: $11.9 \mathrm{M} \Omega$, wash: $12.7 \mathrm{M} \Omega$; one-way ANOVA on ranks, $p=0.823$ ). This suggests that the CCAP effect was solely due to changes in the activation of glutamate receptors. We conclude that CbCCAPr expression in VD contributes to synaptic modulation, which resolves the mismatch between receptor expression and previously published lack of VD responses to CCAP.

\section{Maximal amplitude and concentration dependence of CCAP} elicited $I_{M I}$ differ between LP and IC

Despite substantial variability of $\mathrm{CbCCAPr}$ mRNA expression within cell types, mean transcript levels between some of the cell types were significantly different (Fig. 4). We therefore wanted to determine whether differences in mRNA expression levels between cell types correlate with differences in physiological responses, specifically the magnitude of $I_{\mathrm{MI}}$ evoked by CCAP application. Because the effect of a given amount of $I_{\mathrm{MI}}$ activation on a neuron's activity depends on the background of other ionic conductances, we chose to do this comparison between LP and IC neurons with very different expression levels but otherwise similar excitability. LP expresses CbCCAPr mRNA at a significantly higher level than IC, but both are pyloric neurons that fire in rebound from pacemaker inhibition during the same phase in the pyloric rhythm.

Even with similar receptor affinities, receptor and ion channel activation are only indirectly linked, and differences in the signaling pathway between cell types could yield different quantitative relationships between both. We therefore did not just compare maximal current responses but also tested different concentrations of CCAP. $I_{\mathrm{MI}}$ is usually measured as the difference current obtained from imposing voltage ramps in control saline and in the presence of a neuromodulator (Golowasch and Marder, 1992). Across different individuals, CCAP-evoked $I_{\mathrm{MI}}$ can be quite variable, both with regard to maximal current amplitude and voltage dependence (Goaillard et al., 2009). We found it easier to maintain stable voltage-clamp recordings and monitor current for the $>2 \mathrm{~h}$ needed to apply different CCAP concentrations when a constant voltage was maintained. However, holding neurons at a single voltage would have yielded inaccurate measurements of concentration dependence had the voltage dependence changed at different concentrations within each experiment. Therefore, we first performed voltage ramp measurements in LP at three different CCAP concentrations and compared the resulting IV curves. Figure $7 A$ shows an example of the raw IV curves obtained in control saline and $1 \mu \mathrm{M}$ CCAP. Figure $7 B$ shows IV plots of $I_{\mathrm{MI}}$, calculated as the difference between the raw IV functions at the three different CCAP concentrations. In all three experiments, we found that only the maximal amplitude of $I_{\mathrm{MI}}$ 

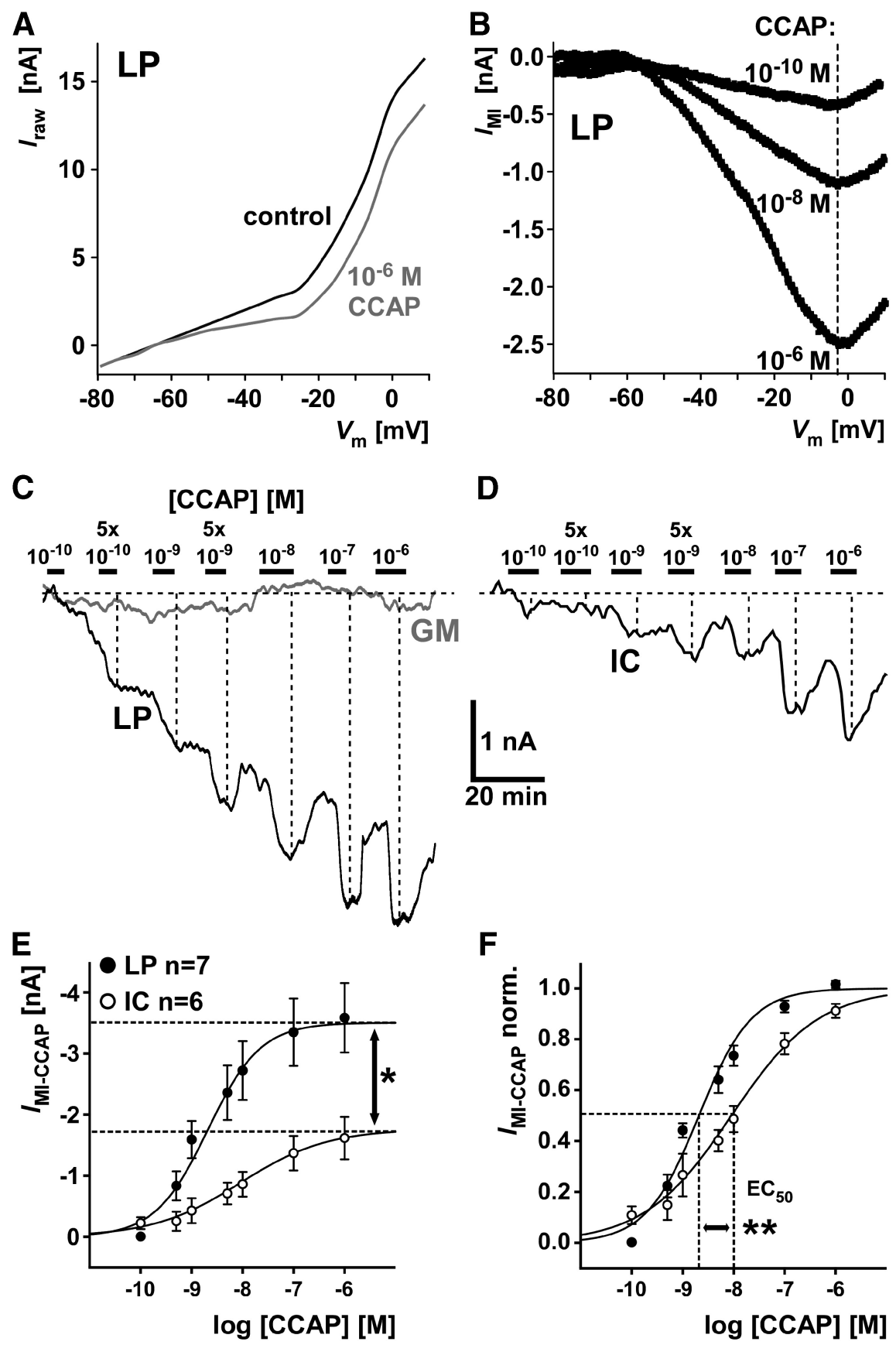

D

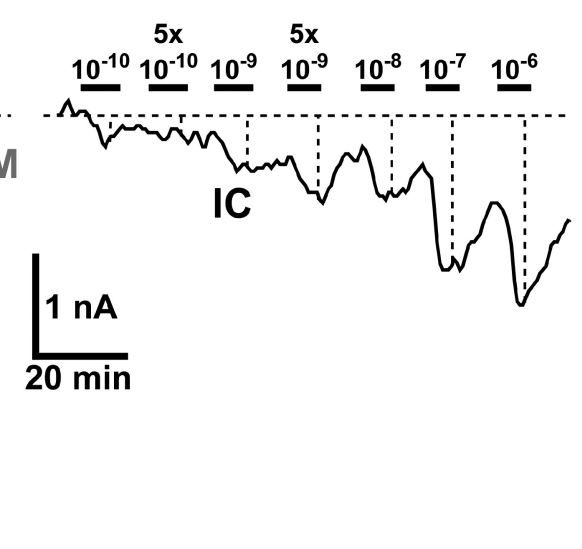

$F$

Figure 7. CCAP-elicited $I_{\mathrm{MI}}$ in LP and IC differs in amplitude and concentration dependence. $\boldsymbol{A}$, Raw currents as a function of voltage, measured from voltage ramps in control saline and CCAP in an LP neuron. $B, I_{M I}$ as a function of voltage, obtained as the difference between raw current-voltage relationships at three different CCAP concentrations. Dashed line indicates that the voltage at which the current peaked did not change with CCAP concentration. C, Filtered current traces from an LP and a GM neuron held at $-20 \mathrm{mV}$, in response to application of CCAP at different concentrations. Dashed lines indicate that inward current responses increased with increasing CCAP concentration. $\boldsymbol{D}$, Filtered current traces from an IC neuron, obtained in the same way as the traces shown in $\boldsymbol{C}$. $\boldsymbol{E}$, Mean current values at different CCAP concentration from measurements in LP and IC. Sigmoid fits were generated from parameters averaged across individual experiments. Maximum current values obtained from fits were significantly larger in LP than in IC (mean \pm SEM: LP: $3.51 \pm 0.55 \mathrm{nA}$; IC: $1.77 \pm 0.37 \mathrm{nA}$; unpaired $t$ test: ${ }^{*} p<0.05$ ). $\boldsymbol{F}$, Same data as in $\boldsymbol{E}$, but normalized to the maximal current fit value in each experiment. Values for $\mathrm{EC}_{50}$ and the slope factor were significantly smaller in $\mathrm{LP}$ than in IC (mean \pm SEM: $E_{50}$, LP: $2.07 \pm 0.68 \mathrm{~nm}$; IC: $9.02 \pm 0.50 \mathrm{~nm}$; unpaired $t$ test: $p<0.01$; slope factor, LP: $0.52 \pm 0.04$; IC: $0.86 \pm 0.10$; unpaired $t$ test: $p<0.01)$. ${ }^{* *} p<0.01$.

(Fig. $7 B$, dashed line) changed at different concentrations, but not the voltage dependence. Therefore, changes in current obtained at a single voltage at different concentrations should only reflect the amount of channel activation and not changes in gating properties.
To determine concentration dependence, we held the cells at $-20 \mathrm{mV}$ and measured the current amplitude evoked by different CCAP concentrations. Figure 7C shows filtered current traces simultaneously obtained from LP and GM at a holding potential of $-20 \mathrm{mV}$ and at different CCAP concentrations. GM is shown here as a control, as it does not express $C b C C A P r$. Figure $7 D$ shows responses of IC from a different experiment. Most other voltage-gated currents were blocked (see Materials and Methods). Application of CCAP at increasing concentrations interspersed with incomplete washes yielded increasing inward current responses in LP and IC (dashed lines), but not in GM. Figure $7 E$ shows mean $I_{\mathrm{MI}}$ values in LP and IC as a function of CCAP concentration. Maximal current values were significantly larger in LP than in IC, matching the much higher $\mathrm{CbCCAPr}$ expression levels shown in Figure 4. Figure $7 F$ shows the same data normalized to maximal current in each experiment. LP and IC $I_{\mathrm{MI}}$ measurements also differed in concentration dependence, as both the $\mathrm{EC}_{50}$ and the slope factor in LP were significantly lower than in IC. A lower slope factor value means a steeper slope (see Materials and Methods). We therefore conclude that the higher expression level of CbCCAPr mRNA in LP is accompanied by stronger activation of $I_{\mathrm{MI}}$ by CCAP, and a higher sensitivity to lower concentrations.

\section{Saturating concentrations of CCAP} activate $I_{M I}$ maximally in LP, but not IC The difference in $I_{\mathrm{MI}}$ responses between LP and IC at saturating CCAP concentrations could be solely due to different numbers of ion channels underlying $I_{\mathrm{MI}}$. In this case, both neuron types would express a sufficient number of CCAP receptors to activate all ion channels present. Saturation would be due to a limited number of ion channels, but LP would express more ion channels and therefore generate a larger current. Alternatively, saturation could occur because all receptors are activated at higher CCAP concentrations before all ion channels are activated. The larger response in LP would then be due to a larger percentage of ion channels opened when all receptors are activated. In this case, LP would show a larger response even if the number of ion channels underlying $I_{\mathrm{MI}}$ was similar in both cell types. We wanted to distinguish between these two cases by using occlusion experiments. A number of different neuromodulators, neuropeptides in particular, can activate $I_{\mathrm{MI}}$ in a given cell type. This convergence was established by showing that 
each neuromodulator activated a current with very similar properties and that the effects of each neuromodulator occlude each other (Swensen and Marder, 2000, 2001). In addition to CCAP, $I_{\mathrm{MI}}$ is activated by the neuropeptide proctolin in both LP and IC (Swensen and Marder, 2001). In a subset of the experiments shown in Figure $7 C-F$, after measuring the current response in $1 \mu \mathrm{M}$ CCAP, we added $1 \mu \mathrm{M}$ proctolin to the bath solution. Figure $8 \mathrm{~A}$ shows the concentration dependence of $I_{\mathrm{MI}}$, normalized to the fit maximum for CCAP alone in each experiment. Dashed lines indicate the fractional increase in $I_{\mathrm{MI}}$ between $1 \mu \mathrm{M}$ CCAP alone and $1 \mu \mathrm{M}$ CCAP $+1 \mu \mathrm{M}$ proctolin. Figure $8 B$ shows the same data normalized to the response in $1 \mu \mathrm{M}$ CCAP $+1 \mu \mathrm{M}$ proctolin. The fraction of $I_{\mathrm{MI}}$ activated by a saturating concentration of CCAP alone was significantly smaller in IC than in LP.

An important caveat in interpreting these data is that, after the repeated CCAP applications in these experiments, nonmaximal $I_{\mathrm{MI}}$ responses to saturating CCAP concentrations could be mostly due to receptor desensitization. The difference between LP and IC could thus reflect differences in desensitization rather than differences in the quantities of receptors or ion channels. We therefore performed separate occlusion experiments, with minimal numbers of repeated applications of only the saturating concentrations. In this case, we used voltage ramps and compared peak currents from IV curves. Figure $8 C$ shows example IV curves from single experiments in which 1 $\mu \mathrm{M}$ CCAP was first applied alone, and then together with $1 \mu \mathrm{M}$ proctolin. The addition of proctolin had little effect on the IV curve in LP but increased the peak current in IC. We also performed experiments in which proctolin was applied alone first, and then together with CCAP. Figure $8 D$ shows bar plots of the mean peak current amplitudes measured in these experiments. Whereas proctolin responses after repeated CCAP applications at different concentrations still caused a small increase in $I_{\mathrm{MI}}$ in LP (Fig. $8 A, B$ ), possibly due to receptor desensitization, the ramp measurements in only saturating concentrations showed complete occlusion of proctolin by CCAP. In contrast, IC responses increased significantly when proctolin was added. The reverse was true when proctolin was applied first, with only LP showing a significant increase in peak currents when CCAP was added.

We conclude that the complete occlusion seen in LP when applying CCAP first, and in IC when applying proctolin first,

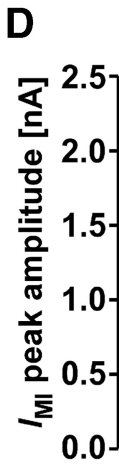

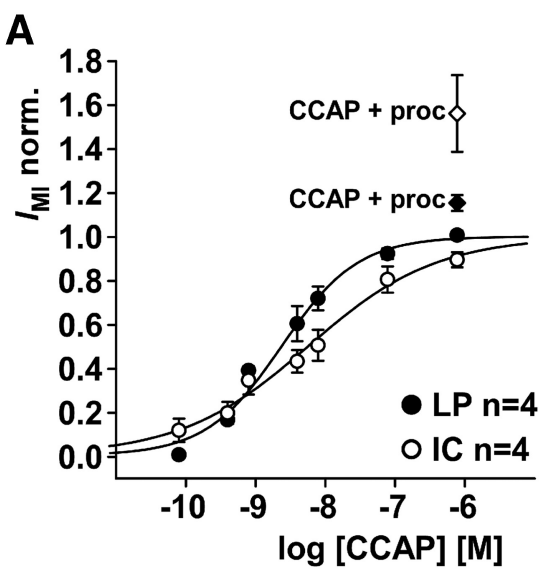
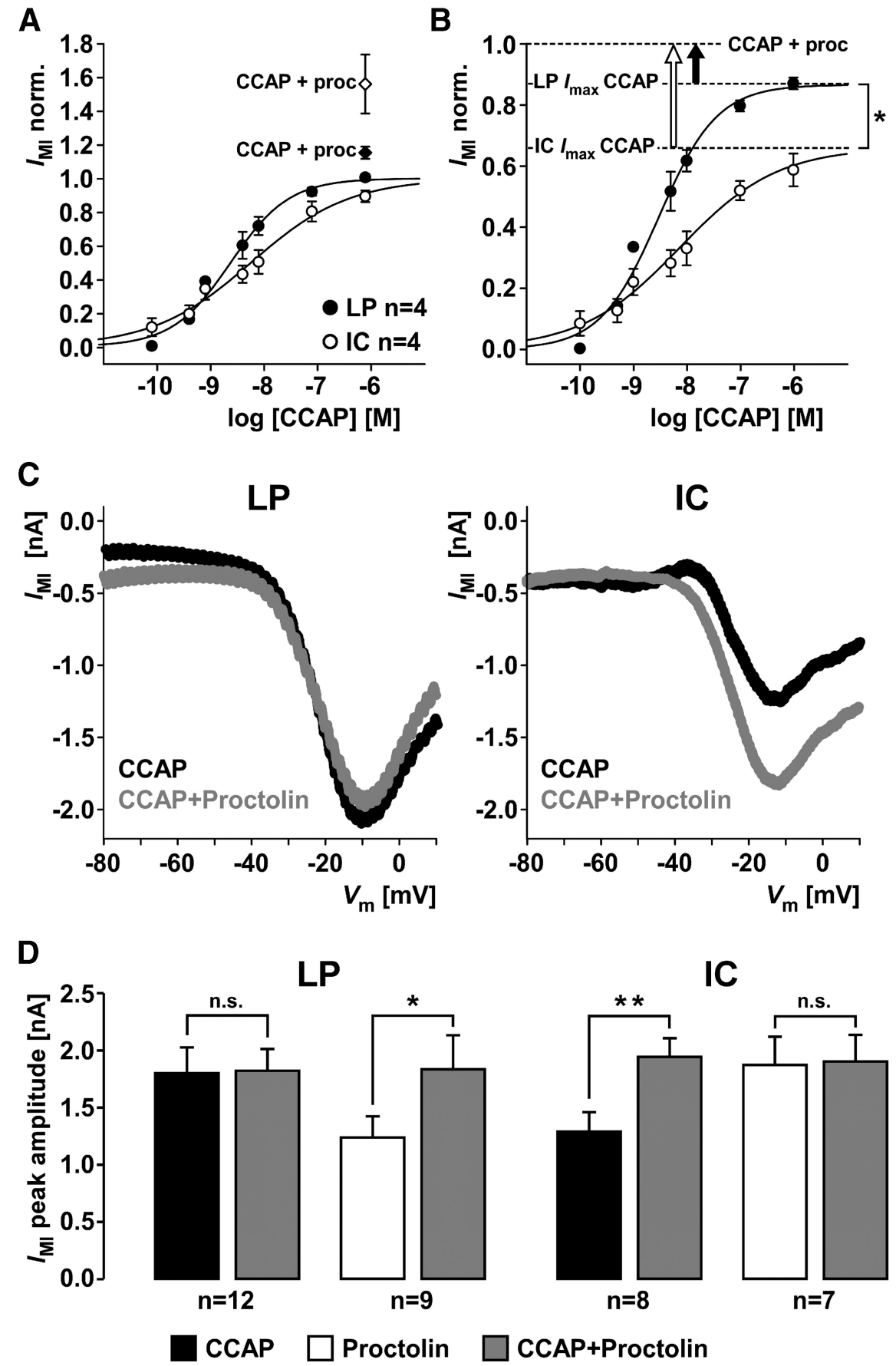

Figure 8. Differences in occlusion of $I_{M I}$ activation by CCAP and proctolin between $L P$ and IC. $A$, Mean current values at different CCAP concentrations from measurements at $-20 \mathrm{mV}$ in $\mathrm{LP}$ and IC, normalized to the maximal current fit value in each experiment. After the concentration series of CCAP, a mix of $1 \mu \mathrm{M}$ CCAP and $1 \mu \mathrm{m}$ proctolin was added. Addition of proctolin yielded larger currents (diamonds) than saturating CCAP concentrations alone (circles). $B$, Same data from the CCAP concentration series as in $\boldsymbol{A}$, but normalized to the responses to the mix of CCAP and proctolin. Addition of proctolin yielded a significantly larger increase in current in IC than in $L P$ (unpaired $t$ test, $p<0.05$ ). C, Example IV curves generated from the difference of responses to voltage ramps in control saline, 1 $\mu \mathrm{M} C \mathrm{CAP}$, and $1 \mu \mathrm{M}$ CCAP $+1 \mu \mathrm{m}$ proctolin. Peak current amplitude did not change in LP but increased in IC. D, Mean peak current amplitudes across experiments, measured from IV curves as shown in C.Current amplitudes in LP did not change between CCAP alone and CCAP + proctolin (paired t test, $p=0.89$ ). In contrast, current amplitudes in IC significantly increased between CCAP alone and CCAP + proctolin (paired $t$ test, $p<0.01$ ). When proctolin was applied alone first, adding CCAP significantly increased current amplitudes in LP (paired $t$ test, $p<0.05$ ), but not IC (paired $t$ test, $p=0.81$ ). ${ }^{*} p<0.05 .{ }^{* *} p<0.01$. n.s., Not significant. 
increase current responses. In IC, the CCAP response saturates because all available CCAP receptors are occupied, but receptors for other neuromodulators can activate additional target ion channels. Saturating CCAP concentrations therefore only activate two-thirds $(66 \%)$ of all available $I_{\mathrm{MI}}$ in IC. We did not test whether $1 \mu \mathrm{M}$ proctolin is a saturating concentration in LP, but the complete occlusion of CCAP responses by proctolin in IC suggests that proctolin activated all available ion channels. When response amplitudes from coapplication of both modulators were pooled, independent of the sequence of application, mean values for LP and IC did not differ (LP: $1.83 \pm 0.16 \mathrm{nA}$ SEM; IC: $1.93 \pm 0.13 \mathrm{nA}$ SEM; unpaired $t$ test: $p=0.67)$. Therefore, the smaller CCAP responses in IC are consistent with a smaller number of CCAP receptors, which matches the significantly lower CbCCAPr mRNA expression shown in Figure 4.

\section{Discussion}

Circuit function is dependent on neuromodulation, a term used for a variety of types of neuronal communication beyond fast neurotransmission (Katz, 1999; Bucher and Marder, 2013), but most commonly for diffuse release of transmitters acting on GPCRs (Hille, 1992). Because GPCR signaling involves pathways shared between different receptors and with multiple intracellular targets, the patterns of activation across different neurons are complex (Harris-Warrick and Johnson, 2010; Bucher and Marder, 2013; Nadim and Bucher, 2014). Even when detailed quantitative information about circuit-wide neuromodulator targets has been gathered, for example, about dopamine effects on STG neurons (Harris-Warrick et al., 1998; Harris-Warrick and Johnson, 2010), the complexity arising from effects on many circuit components has so far precluded comprehensive quantitative models of circuit modulation. We studied quantitative aspects of neuropeptide neuromodulation because neuropeptide effects in the STG appear to be less divergent than amine effects. We show that both receptor expression levels and ion channel activation through these receptors can vary substantially across neuron types.

\section{The identity and distribution of $\mathrm{CbCCAPr}$}

We identified a transcript with high similarity to arthropod CCAP receptors. It is a putative receptor because we did not deorphanize it (e.g., by heterologous protein expression and pharmacology) (Civelli et al., 2013). However, its identity is strongly supported by sequence similarity and expression pattern. Phylogenetic analysis showed a close relationship to arthropod CCAP and mammalian NPS receptors. Sequence comparison was consistent with previous studies of insect CCAP receptor homology, which placed them in subfamily A6 of Rhodopsin-like GPCRs (Joost and Methner, 2002), together with vasopressin and NPS receptors (Park et al., 2002; Li et al., 2011; Pitti and Manoj, 2012). Some insect species have two CCAP receptors, but this is likely due to gene duplication in insect lineages (Li et al., 2011), and we found no evidence of multiple receptor genes.

The transcript was expressed in all nerve tissues tested, consistent with the diverse behaviors under control of CCAP. Expression in the $g m 4$ muscle is consistent with the finding that CCAP enhances gm4 contraction amplitude (Jorge-Rivera et al., 1998). The absence of expression in the heart muscle is surprising, as CCAP was originally named for its effect on heart rate (Stangier et al., 1987). However, crustacean hearts are neurogenic (Cooke, 2002), and CCAP has multiple targets in the regulation of heart contractions, including the cardiac ganglion (Cruz-Bermúdez and Marder,
2007; Fort et al., 2007). Our finding may mean that CCAP mainly acts presynaptically to the muscle in $C$. borealis.

Strong support for receptor identity comes from the expression pattern in the STG. The CbCCAPr transcript was differentially expressed across different neuron types and found in all neurons previously shown to respond to CCAP (Swensen and Marder, 2000, 2001; Kirby and Nusbaum, 2007; DeLong et al., 2009). In most cases, neurons lacking CCAP modulation of excitability did not express $C b C C A P r$. VD was the only cell type that clearly showed expression despite not displaying CCAP effects on excitability. We resolved this mismatch by showing a change in postsynaptic responses to exogenously applied transmitter.

\section{CCAP modulation of the LG to VD synapse}

Neuropeptides alter both excitability and synaptic function in many systems (Taghert and Nitabach, 2012; van den Pol, 2012). However, there are only two reports of neuropeptide effects on synapses in the STG. In the lobster, red pigment concentrating hormone strengthens the synapse from LP to the PD neurons (Thirumalai et al., 2006). In C. borealis, the same synapse is modulated by proctolin (Zhao et al., 2011). Our description of CCAP modulation at the LG to VD synapse is novel in two ways. First, it was previously unknown that a peptide can act on STG neurons without also activating $I_{\mathrm{MI}}$. Effects of red pigment concentrating hormone on excitability in $H$. americanus have not been studied, but in $C$. borealis, both LP and PD show $I_{\mathrm{MI}}$ responses to proctolin (Swensen and Marder, 2001). The only other identified target of peptide modulation is a transient inward current activated by pyrokinin in LG (Rodriguez et al., 2013). This current is also activated in parallel to $I_{\mathrm{MI}}$. Our expression results confirm that neuropeptide receptors are not present in all neurons, but the selective effect on synaptic current in VD means that $I_{\mathrm{MI}}$ activation cannot serve as a proxy for receptor expression. This has to be taken into account for future attempts at circuit-wide mapping of neuropeptide effects.

The second novel aspect is that CCAP modulation at the LG to VD synapse has both presynaptic and postsynaptic components, which has not been tested for other neuropeptides. It is particularly intriguing that presynaptic and postsynaptic effects had opposing signs. As the postsynaptic current responses were clearly reduced by CCAP, the overall strengthening of the synapse can only be explained by a dominant presynaptic enhancement. Presynaptic enhancement and postsynaptic reduction of responses at STG synapses have also been shown for dopamine (Cleland and Selverston, 1997; Johnson and Harris-Warrick, 1997), and Harris-Warrick and Johnson (2010) argue that functionally opposing modulatory mechanisms may stabilize the modulatory state of a network and prevent overmodulation.

\section{Quantitative differences in expression levels and $I_{M I}$ responses and their implications for comodulation}

We found stronger $I_{\mathrm{MI}}$ responses and higher sensitivity to CCAP in LP compared with IC. Overall, low activation thresholds and $\mathrm{EC}_{50}$ values for $I_{\mathrm{MI}}$ in both cells are consistent with the fact that CCAP acts exclusively as a neurohormone in the STG (Christie et al., 1995; Li et al., 2003; Chen et al., 2009) and affects circuit output at low concentrations (Weimann et al., 1997). Similar $\mathrm{EC}_{50}$ values have been found in binding assays for insect CCAP receptors (Lee et al., 2013). It is intriguing that, in addition to the stronger responsiveness of LP, we also found higher $\mathrm{CbCCAPr}$ transcript expression. There is no a priori reason to assume that $I_{\mathrm{MI}}$ responses scale with mRNA expression level. The correlation between mRNA and protein abundance is often poor (Maier et 
al., 2009), and protein and mRNA expression levels are not necessarily at the same ratio in each cell type. In addition, different concentration dependence can be due to differences in receptor affinities (Baker and Hill, 2007). Furthermore, for a given number of receptors activated, there could be quantitative differences in second messenger signaling and activation of target ion channels (Hill, 2006). Stronger support for a correlation between transcript expression levels and $I_{\mathrm{MI}}$ responses would come from testing whether they covary across all cell types in the STG, but this exceeded the scope of our study.

Even without the corroborating evidence of different transcript levels, the finding remains that both the magnitude and concentration dependence of $I_{\mathrm{MI}}$ activation were different between the two cell types tested. In addition, occlusion experiments showed that saturating concentrations of CCAP activate the totally available $I_{\mathrm{MI}}$ in LP, but only approximately two-thirds in IC. These findings have important implications for comodulation. Neuropeptides are often released in conjunction with classical transmitters or other peptides (Hökfelt et al., 2000; Merighi, 2002; Salio et al., 2006; van den Pol, 2012). In the STG, a multitude of neuromodulators are present as neurohormones or released into the neuropil from descending neurons containing multiple modulators (Nusbaum et al., 2001; Marder and Bucher, 2007). Figure $8 B$ illustrates that, at a given concentration, the percentage of totally available $I_{\mathrm{MI}}$ activated can be substantially different between the two cell types. Therefore, nonsaturating concentrations of different neuropeptides present at the same time can have quantitatively very different effects across cell types.

\section{Variability of $\mathrm{CbCCAPr}$ transcript expression levels and $I_{\mathrm{MI}}$ responses}

In addition to varying $\mathrm{CbCCAPr}$ transcript expression across tissues and cell types, we found interindividual differences. Variability in expression in different tissues may be partially due to the fact that CCAP is an important regulator of molting behavior (Ewer and Truman, 1996; Phlippen et al., 2000; Park et al., 2003), and we used wild-caught animals that were likely at different stages in the molt cycle. Within STG cell types, mRNA copy numbers varied substantially. In the STG, transcript expression levels for $\mathrm{K}^{+}$channel genes vary to a similar degree, well correlated with differences in the magnitude of $\mathrm{K}^{+}$currents, a proxy for protein expression (Schulz et al., 2006). Therefore, there is no reason to assume that the variability in $C b C C A P r$ transcripts was due to experimental error. Expression levels of different ion channels covary in a cell type-specific manner (Schulz et al., 2007), suggesting that cellular and synaptic parameters are coregulated to produce robust circuit output from varying underlying parameter values (Prinz et al., 2004; Marder and Goaillard, 2006; Golowasch, 2014; Marder et al., 2014). CCAP elicited $I_{\mathrm{MI}}$ in LP varies substantially (Goaillard et al., 2009), but it was not clear whether this is due to ion channels or receptors. Concentration dependence was relatively consistent across individuals in our study, but variability in expression also suggests that responsiveness to neuromodulators is another free parameter in regulating consistent circuit function. This raises the question whether expression of neuromodulator receptors is coregulated with other parameters determining excitability, particularly $I_{\mathrm{MI}}$. However, currently, the molecular identity of the ion channels carrying $I_{\mathrm{MI}}$ is unknown.

\section{References}

Arakane Y, Li B, Muthukrishnan S, Beeman RW, Kramer KJ, Park Y (2008)

Functional analysis of four neuropeptides, EH, ETH, CCAP and bursicon, and their receptors in adult ecdysis behavior of the red flour beetle, Tribolium castaneum. Mech Dev 125:984-995. CrossRef Medline

Baker JG, Hill SJ (2007) Multiple GPCR conformations and signalling pathways: implications for antagonist affinity estimates. Trends Pharmacol Sci 28:374-381. CrossRef Medline

Bargmann CI (2012) Beyond the connectome: how neuromodulators shape neural circuits. Bioessays 34:458-465. CrossRef Medline

Bargmann CI, Marder E (2013) From the connectome to brain function. Nat Methods 10:483-490. CrossRef Medline

Belmont M, Cazzamali G, Williamson M, Hauser F, Grimmelikhuijzen C) (2006) Identification of four evolutionarily related G protein-coupled receptors from the malaria mosquito Anopheles gambiae. Biochem Biophys Res Commun 344:160-165. CrossRef Medline

Bockaert J, Pin JP (1999) Molecular tinkering of G protein-coupled receptors: an evolutionary success. EMBO J 18:1723-1729. CrossRef Medline

Bucher D, Marder E (2013) SnapShot: neuromodulation. Cell 155:482482.e1. CrossRef Medline

Bucher D, Taylor AL, Marder E (2006) Central pattern generating neurons simultaneously express fast and slow rhythmic activities in the stomatogastric ganglion. J Neurophysiol 95:3617-3632. CrossRef Medline

Cazzamali G, Hauser F, Kobberup S, Williamson M, Grimmelikhuijzen CJ (2003) Molecular identification of a Drosophila G protein-coupled receptor specific for crustacean cardioactive peptide. Biochem Biophys Res Commun 303:146-152. CrossRef Medline

Chen R, Ma M, Hui L, Zhang J, Li L (2009) Measurement of neuropeptides in crustacean hemolymph via MALDI mass spectrometry. J Am Soc Mass Spectrom 20:708-718. CrossRef Medline

Christie AE, Skiebe P, Marder E (1995) Matrix of neuromodulators in neurosecretory structures of the crab Cancer borealis. J Exp Biol 198:24312439. Medline

Civelli O, Reinscheid RK, Zhang Y, Wang Z, Fredriksson R, Schiöth HB (2013) G protein-coupled receptor deorphanizations. Annu Rev Pharmacol Toxicol 53:127-146. CrossRef Medline

Clark MC, Dever TE, Dever JJ, Xu P, Rehder V, Sosa MA, Baro DJ (2004) Arthropod 5-HT2 receptors: a neurohormonal receptor in decapod crustaceans that displays agonist independent activity resulting from an evolutionary alteration to the DRY motif. J Neurosci 24:3421-3435. CrossRef Medline

Clark MC, Khan R, Baro DJ (2008) Crustacean dopamine receptors: localization and $G$ protein coupling in the stomatogastric ganglion. J Neurochem 104:1006-1019. CrossRef Medline

Cleland TA, Selverston AI (1997) Dopaminergic modulation of inhibitory glutamate receptors in the lobster stomatogastric ganglion. J Neurophysiol 78:3450-3452. Medline

Cooke IM (2002) Reliable, responsive pacemaking and pattern generation with minimal cell numbers: the crustacean cardiac ganglion. Biol Bull 202:108-136. CrossRef Medline

Cruz-Bermúdez ND, Marder E (2007) Multiple modulators act on the cardiac ganglion of the crab, Cancer borealis. J Exp Biol 210:2873-2884. CrossRef Medline

DeLong ND, Kirby MS, Blitz DM, Nusbaum MP (2009) Parallel regulation of a modulator-activated current via distinct dynamics underlies comodulation of motor circuit output. J Neurosci 29:12355-12367. CrossRef Medline

Donini A, Agricola H, Lange AB (2001) Crustacean cardioactive peptide is a modulator of oviduct contractions in Locusta migratoria. J Insect Physiol 47:277-285. CrossRef Medline

Donini A, Ngo C, Lange AB (2002) Evidence for crustacean cardioactive peptide-like innervation of the gut in Locusta migratoria. Peptides 23 : 1915-1923. CrossRef Medline

Estévez-Lao TY, Boyce DS, Honegger HW, Hillyer JF (2013) Cardioacceleratory function of the neurohormone CCAP in the mosquito Anopheles gambiae. J Exp Biol 216:601-613. CrossRef Medline

Ewer J, Truman JW (1996) Increases in cyclic 3', 5' -guanosine monophosphate (cGMP) occur at ecdysis in an evolutionarily conserved crustacean cardioactive peptide-immunoreactive insect neuronal network. J Comp Neurol 370:330-341. CrossRef Medline

Fort TJ, García-Crescioni K, Agricola HJ, Brezina V, Miller MW (2007) Regulation of the crab heartbeat by crustacean cardioactive peptide (CCAP): central and peripheral actions. J Neurophysiol 97:3407-3420. CrossRef Medline

Goaillard JM, Taylor AL, Schulz DJ, Marder E (2009) Functional conse- 
quences of animal-to-animal variation in circuit parameters. Nat Neurosci 12:1424-1430. CrossRef Medline

Golowasch J (2014) Ionic current variability and functional stability in the nervous system. BioScience 64:570-580. CrossRef

Golowasch J, Marder E (1992) Proctolin activates an inward current whose voltage dependence is modified by extracellular $\mathrm{Ca}^{2+}$. J Neurosci 12:810817. Medline

Graubard K, Raper JA, Hartline DK (1980) Graded synaptic transmission between spiking neurons. Proc Natl Acad Sci U S A 77:3733-3735. CrossRef Medline

Harris-Warrick RM (2011) Neuromodulation and flexibility in Central Pattern Generator networks. Curr Opin Neurobiol 21:685-692. CrossRef Medline

Harris-Warrick RM, Johnson BR (2010) Checks and balances in neuromodulation. Front Behav Neurosci 4:pii47. CrossRef Medline

Harris-Warrick RM, Johnson BR, Peck JH, Kloppenburg P, Ayali A, Skarbinski J (1998) Distributed effects of dopamine modulation in the crustacean pyloric network. Ann N Y Acad Sci 860:155-167. CrossRef Medline

Hill SJ (2006) G-protein-coupled receptors: past, present and future. Br J Pharmacol 147 [Suppl 1]:S27-S37.

Hille B (1992) G protein-coupled mechanisms and nervous signaling. Neuron 9:187-195. CrossRef Medline

Hofmann K, Stoffel W (1993) TMbase: a database of membrane spanning proteins segments. Biol Chem Hoppe Seyler 374:166.

Hökfelt T, Broberger C, Xu ZQ, Sergeyev V, Ubink R, Diez M (2000) Neuropeptides: an overview. Neuropharmacology 39:1337-1356. CrossRef Medline

Johnson BR, Harris-Warrick RM (1997) Amine modulation of glutamate responses from pyloric motor neurons in lobster stomatogastric ganglion. J Neurophysiol 78:3210-3221.

Jones DT, Taylor WR, Thornton JM (1992) The rapid generation of mutation data matrices from protein sequences. Comput Appl Biosci 8:275282. Medline

Joost P, Methner A (2002) Phylogenetic analysis of 277 human G-proteincoupled receptors as a tool for the prediction of orphan receptor ligands. Genome Biol 3:RESEARCH0063. CrossRef Medline

Jordan LM, Sławińska U (2011) Modulation of rhythmic movement: control of coordination. Prog Brain Res 188:181-195. CrossRef Medline

Jorge-Rivera JC, Sen K, Birmingham JT, Abbott LF, Marder E (1998) Temporal dynamics of convergent modulation at a crustacean neuromuscular junction. J Neurophysiol 80:2559-2570.

Katz PS, ed (1999) Beyond neurotransmission: neuromodulation and its importance for information processing. Oxford: UP.

Kilman VL, Marder E (1996) Ultrastructure of the stomatogastric ganglion neuropil of the crab, Cancer borealis. J Comp Neurol 374:362-375. CrossRef Medline

Kirby MS, Nusbaum MP (2007) Peptide hormone modulation of a neuronally modulated motor circuit. J Neurophysiol 98:3206-3220. CrossRef Medline

Lee D, Vanden Broeck J, Lange AB (2013) Identification and expression of the CCAP receptor in the Chagas' disease vector, Rhodnius prolixus, and its involvement in cardiac control. PLoS One 8:e68897. CrossRef Medline

Li B, Beeman RW, Park Y (2011) Functions of duplicated genes encoding CCAP receptors in the red flour beetle, Tribolium castaneum. J Insect Physiol 57:1190-1197. CrossRef Medline

Li L, Kelley WP, Billimoria CP, Christie AE, Pulver SR, Sweedler JV, Marder E (2003) Mass spectrometric investigation of the neuropeptide complement and release in the pericardial organs of the crab, Cancer borealis. J Neurochem 87:642-656. CrossRef Medline

Maier T, Güell M, Serrano L (2009) Correlation of mRNA and protein in complex biological samples. FEBS Lett 583:3966-3973. CrossRef Medline

Mamiya A, Manor Y, Nadim F (2003) Short-term dynamics of a mixed chemical and electrical synapse in a rhythmic network. J Neurosci 23: 9557-9564. Medline

Manor Y, Nadim F, Abbott LF, Marder E (1997) Temporal dynamics of graded synaptic transmission in the lobster stomatogastric ganglion. J Neurosci 17:5610-5621. Medline

Marder E (2012) Neuromodulation of neuronal circuits: back to the future. Neuron 76:1-11. CrossRef Medline

Marder E, Bucher D (2007) Understanding circuit dynamics using the stomatogastric nervous system of lobsters and crabs. Annu Rev Physiol 69: 291-316. CrossRef Medline
Marder E, Goaillard JM (2006) Variability, compensation and homeostasis in neuron and network function. Nat Rev Neurosci 7:563-574. CrossRef Medline

Marder E, Bucher D, Schulz DJ, Taylor AL (2005) Invertebrate central pattern generation moves along. Curr Biol 15:R685-R699. CrossRef Medline

Marder E, Goeritz ML, Otopalik AG (2014) Robust circuit rhythms in small circuits arise from variable circuit components and mechanisms. Curr Opin Neurobiol 31:156-163. CrossRef Medline

Merighi A (2002) Costorage and coexistence of neuropeptides in the mammalian CNS. Prog Neurobiol 66:161-190. CrossRef Medline

Nadim F, Bucher D (2014) Neuromodulation of neurons and synapses. Curr Opin Neurobiol 29:48-56. CrossRef Medline

Nadim F, Manor Y (2000) The role of short-term synaptic dynamics in motor control. Curr Opin Neurobiol 10:683-690. CrossRef Medline

Nusbaum MP, Beenhakker MP (2002) A small-systems approach to motor pattern generation. Nature 417:343-350. CrossRef Medline

Nusbaum MP, Blitz DM, Swensen AM, Wood D, Marder E (2001) The roles of co-transmission in neural network modulation. Trends Neurosci 24: 146-154. CrossRef Medline

Park JH, Schroeder AJ, Helfrich-Förster C, Jackson FR, Ewer J (2003) Targeted ablation of CCAP neuropeptide-containing neurons of Drosophila causes specific defects in execution and circadian timing of ecdysis behavior. Development 130:2645-2656. CrossRef Medline

Park Y, Kim YJ, Adams ME (2002) Identification of G protein-coupled receptors for Drosophila PRXamide peptides, CCAP, corazonin, and AKH supports a theory of ligand-receptor coevolution. Proc Natl Acad Sci U S A 99:11423-11428. CrossRef Medline

Park Y, Aikins J, Wang LJ, Beeman RW, Oppert B, Lord JC, Brown SJ, Lorenzen MD, Richards S, Weinstock GM, Gibbs RA (2008) Analysis of transcriptome data in the red flour beetle, Tribolium castaneum. Insect Biochem Mol Biol 38:380-386. CrossRef Medline

Phlippen MK, Webster SG, Chung JS, Dircksen H (2000) Ecdysis of decapod crustaceans is associated with a dramatic release of crustacean cardioactive peptide into the haemolymph. J Exp Biol 203:521-536. Medline

Pitti T, Manoj N (2012) Molecular evolution of the neuropeptide S receptor. PLoS One 7:e34046. CrossRef Medline

Prinz AA, Bucher D, Marder E (2004) Similar network activity from disparate circuit parameters. Nat Neurosci 7:1345-1352. CrossRef Medline

Prinz H (2010) Hill coefficients, dose-response curves and allosteric mechanisms. J Chem Biol 3:37-44. CrossRef Medline

Richards KS, Marder E (2000) The actions of crustacean cardioactive peptide on adult and developing stomatogastric ganglion motor patterns. J Neurobiol 44:31-44. CrossRef Medline

Rodriguez JC, Blitz DM, Nusbaum MP (2013) Convergent rhythm generation from divergent cellular mechanisms. J Neurosci 33:18047-18064. CrossRef Medline

Sakai T, Satake H, Minakata H, Takeda M (2004) Characterization of crustacean cardioactive peptide as a novel insect midgut factor: isolation, localization, and stimulation of alpha-amylase activity and gut contraction. Endocrinology 145:5671-5678. CrossRef Medline

Sakai T, Satake H, Takeda M (2006) Nutrient-induced alpha-amylase and protease activity is regulated by crustacean cardioactive peptide (CCAP) in the cockroach midgut. Peptides 27:2157-2164. CrossRef Medline

Salio C, Lossi L, Ferrini F, Merighi A (2006) Neuropeptides as synaptic transmitters. Cell Tissue Res 326:583-598. CrossRef Medline

Schulz DJ, Goaillard JM, Marder E (2006) Variable channel expression in identified single and electrically coupled neurons in different animals. Nat Neurosci 9:356-362. CrossRef Medline

Schulz DJ, Goaillard JM, Marder EE (2007) Quantitative expression profiling of identified neurons reveals cell-specific constraints on highly variable levels of gene expression. Proc Natl Acad Sci U S A 104:13187-13191. CrossRef Medline

Stangier J, Hilbich C, Beyreuther K, Keller R (1987) Unusual cardioactive peptide (CCAP) from pericardial organs of the shore crab Carcinus maenas. Proc Natl Acad Sci U S A 84:575-579. CrossRef Medline

Stein W (2009) Modulation of stomatogastric rhythms. J Comp Physiol A Neuroethol Sens Neural Behav Physiol 195:989-1009. CrossRef Medline

Swensen AM, Marder E (2000) Multiple peptides converge to activate the same voltage-dependent current in a central pattern-generating circuit. J Neurosci 20:6752-6759. Medline 
Swensen AM, Marder E (2001) Modulators with convergent cellular actions elicit distinct circuit outputs. J Neurosci 21:4050-4058. Medline

Taghert PH, Nitabach MN (2012) Peptide neuromodulation in invertebrate model systems. Neuron 76:82-97. CrossRef Medline

Tamura K, Stecher G, Peterson D, Filipski A, Kumar S (2013) MEGA6: molecular evolutionary genetics analysis version 6.0. Mol Biol Evol 30:27252729. CrossRef Medline

Thirumalai V, Prinz AA, Johnson CD, Marder E (2006) Red pigment concentrating hormone strongly enhances the strength of the feedback to the pyloric rhythm oscillator but has little effect on pyloric rhythm period. J Neurophysiol 95:1762-1770. CrossRef Medline

Tublitz N (1989) Insect cardioactive peptides: neurohormonal regulation of cardiac activity by two cardioacceleratory peptides during flight in the tobacco hawkmoth, Manduca sexta. J Exp Biol 142:31-48. Medline

van den Pol AN (2012) Neuropeptide transmission in brain circuits. Neuron 76:98-115. CrossRef Medline

Veelaert D, Passier P, Devreese B, Vanden Broeck J, Van Beeumen J, Vullings HG, Diederen JH, Schoofs L, De Loof A (1997) Isolation and characterization of an adipokinetic hormone release-inducing factor in locusts: the crustacean cardioactive peptide. Endocrinology 138:138-142. CrossRef Medline

Wasielewski O, Skonieczna M (2008) Pleiotropic effects of the neuropeptides CCAP and myosuppressin in the beetle, Tenebrio molitor L. J Comp Physiol B 178:877-885. CrossRef Medline

Weimann JM, Meyrand P, Marder E (1991) Neurons that form multiple pattern generators: identification and multiple activity patterns of gastric/ pyloric neurons in the crab stomatogastric system. J Neurophysiol 65: 111-122. Medline

Weimann JM, Skiebe P, Heinzel HG, Soto C, Kopell N, Jorge-Rivera JC, Marder E (1997) Modulation of oscillator interactions in the crab stomatogastric ganglion by crustacean cardioactive peptide. J Neurosci 17: 1748-1760. Medline

Wess J (1997) G-protein-coupled receptors: molecular mechanisms involved in receptor activation and selectivity of G-protein recognition. FASEB J 11:346-354. Medline

Zhao S, Sheibanie AF, Oh M, Rabbah P, Nadim F (2011) Peptide neuromodulation of synaptic dynamics in an oscillatory network. J Neurosci 31:13991-14004. CrossRef Medline 